\title{
A new $\mathrm{V}_{2} \mathrm{O}_{5}-\mathrm{MoO}_{3}-\mathrm{TiO}_{2}-\mathrm{SO}_{4}{ }^{2-}$ nanostructured aerogel catalyst for Diesel DeNOx
}

\section{technology}

\author{
Jihene Arfaoui $^{*}$, Abdelhamid Ghorbel ${ }^{\mathrm{a}}$, Carolina Petitto $^{\mathrm{b}}$, Gerard Delahay ${ }^{\mathrm{b}}$ \\ ${ }^{a}$ Université Tunis El Manar, Laboratoire de Chimie des Matériaux et Catalyse, Département de Chimie, Faculté \\ des Sciences de Tunis, Campus Universitaire Farhat Hached d'El Manar, 2092, Tunis, Tunisia. \\ ${ }^{\mathrm{b}}$ ICGM, University of Montpellier, ENSCM (MACS), CNRS, Montpellier, France
}

* Corresponding author: E-mail address: jihene.arfaoui@,fst.utm.tn Tel: +216 23020273, Fax: +216 71875008

\begin{abstract}
New $\mathrm{V}_{2} \mathrm{O}_{5}-\mathrm{MoO}_{3}-\mathrm{TiO}_{2}-\mathrm{SO}_{4}{ }^{2-}$ nanostructured aerogel catalyst, containing $\mathrm{V}$ and $\mathrm{Mo}$ amounts representative of $\mathrm{V}_{2} \mathrm{O}_{5}-\mathrm{MoO}_{3} / \mathrm{TiO}_{2}$ commercial SCR catalyst, was developed via the one step sol gel method combined to supercritical drying approach for the low temperature selective catalytic reduction of $\mathrm{NO}$ by $\mathrm{NH}_{3}$, in excess $\mathrm{O}_{2}$. The new $\mathrm{V}_{2} \mathrm{O}_{5}-\mathrm{MoO}_{3}-\mathrm{TiO}_{2}-\mathrm{SO}_{4}{ }^{2-}$ system was analysed by XRD, $\mathrm{N}_{2}$-Physisorption, $\mathrm{H}_{2}-\mathrm{TPR}, \mathrm{NH}_{3}-\mathrm{TPD}$, Raman, XPS and DRUVVis spectroscopy. The elaboration and characterization of $\mathrm{TiO}_{2}, \mathrm{~V}_{2} \mathrm{O}_{5}-\mathrm{TiO}_{2}, \mathrm{MoO}_{3}-\mathrm{TiO}_{2}, \mathrm{~V}_{2} \mathrm{O}_{5^{-}}$ $\mathrm{MoO}_{3}-\mathrm{TiO}_{2}, \mathrm{TiO}_{2}-\mathrm{SO}_{4}{ }^{2-}, \mathrm{V}_{2} \mathrm{O}_{5}-\mathrm{TiO}_{2}-\mathrm{SO}_{4}{ }^{2-}$ and $\mathrm{MoO}_{3}-\mathrm{TiO}_{2}-\mathrm{SO}_{4}{ }^{2-}$ aerogel samples were reported also in this work. The results proved the successful synthesis of nanostructured aerogel materials with a good cristallinity of $\mathrm{TiO}_{2}$ anatase phase, developed mesoporous texture and nanometer size as a new SCR catalysts. $\mathrm{V}, \mathrm{Mo}$ and $\mathrm{SO}_{4}{ }^{2-}$ were found highly dispersed on the $\mathrm{TiO}_{2}$ surface, their presence and the diverse interactions, developed between them, strongly affect the physicochemical properties and catalytic behaviour of the derived sol-gel solids. Among all the samples investigated, the new aerogel $\mathrm{V}_{2} \mathrm{O}_{5}-\mathrm{MoO}_{3}-\mathrm{TiO}_{2}-\mathrm{SO}_{4}{ }^{2-}$ was found to be the most efficient catalyst for the low temperature NO-SCR: compared to a $\mathrm{V}_{2} \mathrm{O}_{5}-\mathrm{WO}_{3} / \mathrm{TiO}_{2}$ commercial catalyst (EUROCAT), it demonstrates a similar SCR activity in the $200-375{ }^{\circ} \mathrm{C}$ temperature range, but, at higher temperatures $\left(375-500{ }^{\circ} \mathrm{C}\right)$, it exhibits superior catalytic efficiencies. A total $\mathrm{NO}$ conversion into $\mathrm{N}_{2}$ is achieved in the $450-500{ }^{\circ} \mathrm{C}$ temperature range
\end{abstract}


over the new $\mathrm{V}_{2} \mathrm{O}_{5}-\mathrm{MoO}_{3}-\mathrm{TiO}_{2}-\mathrm{SO}_{4}{ }^{2-}$ nanostructured aerogel catalyst, when the $\mathrm{NH}_{3}-\mathrm{SCR}$ reaction was realized using $1000 \mathrm{ppm} \mathrm{NO}$ and $1000 \mathrm{ppm} \mathrm{NH}_{3}$, in the presence of $3.5 \% \mathrm{H}_{2} \mathrm{O}$. Key words: Aerogel; $\mathrm{V}_{2} \mathrm{O}_{5}-\mathrm{MoO}_{3}-\mathrm{TiO}_{2}$; Sulfate; $\mathrm{V}-\mathrm{SO}_{4}{ }^{2-}-\mathrm{Mo}$ interactions; Commercial SCR catalyst; Diesel De-NO technology. 


\section{Introduction}

Nitrogen oxides (NOx), emitted from stationary and mobile sources are the major air pollutants which can cause seriously adverse environmental and human health problems, including ozone depletion, acid rain, greenhouse effects, haze, photochemical smog, eye and throat irritation, chest tightness, nausea and headache, respiratory diseases like bronchitis, pneumonia, etc. $[1,2]$. Selective catalytic reduction of $\mathrm{NO}_{\mathrm{x}}$ by ammonia $\left(\mathrm{NO}-\mathrm{SCR}\right.$ or $\mathrm{NH}_{3}-$ SCR), in excess $\mathrm{O}_{2}$, has been considered as the most efficient available technology for nitrogen oxide removal from stationary sources and diesel exhausts [3-4]. $\mathrm{V}_{2} \mathrm{O}_{5}-\mathrm{WO}_{3}\left(\mathrm{MoO}_{3}\right) / \mathrm{TiO}_{2}$ commercial catalysts, containing $\sim 0.1-2$ wt. $\% \mathrm{~V}_{2} \mathrm{O}_{5}$ and 10 wt. $\% \mathrm{WO}_{3}$ or 6 wt. $\% \mathrm{MoO}_{3}$ (generally deposited by the impregnation method), are still widely used in thermal power plants and coal-fired boilers [5-7]. $\mathrm{V}_{2} \mathrm{O}_{5}$ represents the most active phase, while, $\mathrm{WO}_{3}$ and $\mathrm{MoO}_{3}$ act as 'chemical' and 'structural' promoter by enlarging the temperature window of the SCR reaction, limiting the oxidation of $\mathrm{SO}_{2}$ and improving the mechanical strength of catalysts [8,9]. Analogous catalytic systems, optimized for Diesel vehicle applications, contain higher amount of vanadia (1.5-2 wt. \%) to achieve high DeNO $_{x}$ activity [10]. Nevertheless, the high starting temperature, the narrow active temperature window $\left(300-400{ }^{\circ} \mathrm{C}\right)$ and the low $\mathrm{N}_{2}$ selectivity at high temperature remain the major drawbacks of $\mathrm{V}_{2} \mathrm{O}_{5}-\mathrm{WO}_{3}\left(\mathrm{MoO}_{3}\right) / \mathrm{TiO}_{2}$ industrial systems $[11,12]$.

It is estimated that diesel engines contribute to about $85 \%$ of all the $\mathrm{NO}_{\mathrm{x}}$ emissions from mobile sources, principally in the form of $\mathrm{NO}[13,14]$. Therefore, the emission of $\mathrm{NO}_{\mathrm{x}}$ from vehicle is limited by various standards, such as Euro V and Euro VI. In Euro V, it is limited to $<180 \mathrm{mg} / \mathrm{Km}$ for diesel-driven engine and $60 \mathrm{mg} / \mathrm{Km}$ for petrol-driven engine. However, the $\mathrm{NO}_{\mathrm{x}}$ emissions from Euro VI is $55 \%$ lower than that from Euro V $[15,16]$. 
According to the literature, the SCR process for mobile applications can be summarized by the followings main reaction [17-18]:

$$
\begin{array}{ll}
4 \mathrm{NH}_{3}+4 \mathrm{NO}+\mathrm{O}_{2} \rightarrow 4 \mathrm{~N}_{2}+6 \mathrm{H}_{2} \mathrm{O} & \mathrm{R} 1 \text { (Standard SCR) } \\
2 \mathrm{NH}_{3}+\mathrm{NO}+\mathrm{NO}_{2} \rightarrow 2 \mathrm{~N}_{2}+3 \mathrm{H}_{2} \mathrm{O} & \mathrm{R} 2 \text { (Fast SCR) } \\
8 \mathrm{NH}_{3}+6 \mathrm{NO}_{2} \rightarrow 7 \mathrm{~N}_{2}+12 \mathrm{H}_{2} \mathrm{O} & \mathrm{R} 3\left(\mathrm{NO}_{2}-\mathrm{SCR}\right)
\end{array}
$$

In diesel engine, this process requires a highly efficient catalyst operating in oxygen rich exhaust gas, at high gas hourly space velocity (GHSV) over a wide temperature range (200-500 $\left.{ }^{\circ} \mathrm{C}\right)[19]$. The three way catalysts (TWC) have been successfully used by the automotive industry for the simultaneously elimination of harmful emissions (NOx, $\mathrm{CO}$ and unburned hydrocarbon (HC)) from gasoline-powered engines that work in stoichiometric air-to-fuel ratio. However, this system cannot be used for diesel vehicles, because of the oxygen-rich atmosphere where NOx reduction cannot be easily achieved [20-22]. Zeolite-based catalysts promoted by transition metals such as $\mathrm{Fe}$ and $\mathrm{Cu}$ are being considered for practical applications in diesel emission control [19]. Nevertheless, the insufficient low-temperature activity of Fe-ZSM-5 and the poor hydrothermal stability of Cu-ZSM-5 are neither satisfactorily solved [23].

Owing the required higher De- $\mathrm{NO}_{\mathrm{x}}$ efficiency and in order to meet the increasingly stringent legislations for $\mathrm{NO}_{\mathrm{x}}$ emission in mobile applications, a lot of efforts have been recently concentrated on the optimization of SCR catalysts for broadening the active De- $\mathrm{NO}_{\mathrm{x}}$ temperature window as widely as possible, enhancing the catalysts durability and reducing the cost of De- $\mathrm{NO}_{\mathrm{x}}$ systems [24]. Despite the low cost of Mo (in comparison with W "for which the price has risen about 30 times compared to ten years ago") and in spite of the fact that $\mathrm{V}_{2} \mathrm{O}_{5^{-}}$ $\mathrm{MoO}_{3} / \mathrm{TiO}_{2}$ SCR catalysts have been introduced on the commercial scale, only a few studies related to this subject have been reported in the literature [ $25-29,30-33]$. In this framework, L. Lietti et al. $[25,26]$ studied the $\mathrm{V}_{2} \mathrm{O}_{5}-\mathrm{MoO}_{3} / \mathrm{TiO}_{2}$ De- $\mathrm{NO}_{\mathrm{x}} \mathrm{SCR}$ catalysts, prepared by the incipient wetness method, and suggested that molybdenum oxide acts as "chemical" promoter 4 
for SCR reaction besides playing "structural" promoter for the catalyst. Moreover, L. Zhu et al. [28] showed that the addition of 5 wt. $\% \mathrm{MoO}_{3}$ enhances the low temperature $\left(150-300{ }^{\circ} \mathrm{C}\right)$ $\mathrm{NH}_{3}$-SCR activity of VWTi catalysts. Recently, $\mathrm{Xu}$ et al. [30] studied the $\mathrm{SO}_{2}$ tolerance of $\mathrm{V}_{2} \mathrm{O}_{5}-\mathrm{MoO}_{3} / \mathrm{TiO}_{2}$ catalyst. They concluded that a high proportioned stable tridentate sulfates on VMoTi-S surface act as strong Brønsted acid sites which liberates more active polymeric vanadates to activate the adsorbed $\mathrm{NH}_{4}{ }^{+}$to form $-\mathrm{NH}_{2}$ species as a crucial intermediate for $\mathrm{NH}_{3}-$ SCR reaction. More recently, Wu et al. [32], investigated the effect of doping of expanded graphite (EG) with different methods on $\mathrm{SCR}$ performance over $\mathrm{V}_{2} \mathrm{O}_{5}-\mathrm{MoO}_{3} / \mathrm{TiO}_{2}$ [32].Their results demonstrated that doping of EG by high shear method enhances the surface area, increases Brönsted and Lewis acid sites, raises the $\mathrm{VO}^{2+}$ and adsorbed surface oxygen species and consequently leads to the most active SCR catalyst.

Over the last few years, several studies proved that the direct sulfating of SCR catalysts (such as: $\mathrm{V}_{2} \mathrm{O}_{5}-\mathrm{CeO}_{2}-\mathrm{TiO}_{2}-\mathrm{SO}_{4}{ }^{2-}[34], \mathrm{V}_{2} \mathrm{O}_{5}-\mathrm{SO}_{4}{ }^{2-} / \mathrm{TiO}_{2}$ [35], $\mathrm{V}_{2} \mathrm{O}_{5}-\mathrm{WO}_{3}-\mathrm{TiO}_{2}-\mathrm{SO}_{4}{ }^{2-}$ [36] and $\left.\mathrm{CeO}_{2}-\mathrm{ZrO}_{2}-\mathrm{NiO}-\mathrm{SO}_{4}{ }^{2-}[37]\right)$ improves their acidity, enhances their stability and, thus, increases both their high temperature activity and $\mathrm{N}_{2}$ selectivity. Nevertheless, up to date any direct modification of $\mathrm{V}_{2} \mathrm{O}_{5}-\mathrm{MoO}_{3} / \mathrm{TiO}_{2} \mathrm{SCR}$ catalyst by sulfate ions has not been investigated.

Taking into account the key role of sulfate groups in increasing the high temperature SCR activity (NO conversion and $\mathrm{N}_{2}$ selectivity) and that until now no studies devoted to the direct sulfating of $\mathrm{V}_{2} \mathrm{O}_{5}-\mathrm{MoO}_{3} / \mathrm{TiO}_{2} \mathrm{SCR}$ catalyst has been described in the literature, we have developed in this work, using the one step sol gel method combined to supercritical drying approach, a new $\mathrm{V}_{2} \mathrm{O}_{5}-\mathrm{MoO}_{3}-\mathrm{TiO}_{2}-\mathrm{SO}_{4}{ }^{2-}$ aerogel catalyst, containing $\mathrm{V}$ and Mo loadings representative of $\mathrm{V}_{2} \mathrm{O}_{5}-\mathrm{MoO}_{3} / \mathrm{TiO}_{2}$ commercial SCR one (2 wt. $\% \mathrm{~V}_{2} \mathrm{O}_{5}$ and 6 wt. $\% \mathrm{MoO}_{3}$ ), for De-NO $\mathrm{N}_{\mathrm{x}}$ ing in Diesel Engines in a wide temperature range $\left(150-500{ }^{\circ} \mathrm{C}\right)$, under oxygen rich conditions and at relatively high GHSV $\left(120.000 \mathrm{~h}^{-1}\right)$.

\section{Experimental}




\section{1. Synthesis of aerogel catalysts}

The $\mathrm{TiO}_{2}$ support and the aerogel mixed oxides $\left(\mathrm{V}_{2} \mathrm{O}_{5}-\mathrm{TiO}_{2}, \mathrm{MoO}_{3}-\mathrm{TiO}_{2}, \mathrm{~V}_{2} \mathrm{O}_{5}-\mathrm{MoO}_{3}-\right.$ $\mathrm{TiO}_{2}, \mathrm{TiO}_{2}-\mathrm{SO}_{4}{ }^{2-}, \mathrm{V}_{2} \mathrm{O}_{5}-\mathrm{TiO}_{2}-\mathrm{SO}_{4}{ }^{2-}, \mathrm{MoO}_{3}-\mathrm{TiO}_{2}-\mathrm{SO}_{4}{ }^{2-}$ and $\left.\mathrm{V}_{2} \mathrm{O}_{5}-\mathrm{MoO}_{3}-\mathrm{TiO}_{2}-\mathrm{SO}_{4}{ }^{2-}\right)$ were prepared via the one step sol-gel method using a similar procedure to that reported in our previous work [34]: First, $\mathrm{Ti}(\mathrm{IV})$ isopropoxide $\left(\mathrm{Ti}\left(\mathrm{O}_{\mathrm{i}} \mathrm{C}_{3} \mathrm{H}_{7}\right)_{4}\right.$, Sigma-Aldrich, 97\%) was dissolved in anhydrous ethanol $\left(\mathrm{C}_{2} \mathrm{H}_{6} \mathrm{O}\right.$, Aldrich, $\left.99.8 \%\right)$. Then, Ethyl acetoacetate $\left(\mathrm{C}_{6} \mathrm{H}_{10} \mathrm{O}_{3}\right.$, Fluka, $>99.5 \%$ ) was added to the mixture (with a molar ratio Etacac $/ \mathrm{Ti}=1$ ) for the control of the reaction kinetics. After ageing under stirring, at room temperature, a dilute solution of $\mathrm{HNO}_{3}$ $(0.1 \mathrm{M})$ was added to accomplish hydrolysis according to the molar ratio $\mathrm{H}_{2} \mathrm{O} / \mathrm{Ti}=10$. Finally, the obtained gel was transformed into $\mathrm{TiO}_{2}$ aerogel oxide by supercritical drying in the autoclave (at $\mathrm{T}=243{ }^{\circ} \mathrm{C}$ and $\mathrm{P}=63$ bar). For the elaboration of $\mathrm{V}_{2} \mathrm{O}_{5}-\mathrm{TiO}_{2}, \mathrm{MoO}_{3}-\mathrm{TiO}_{2}, \mathrm{~V}_{2} \mathrm{O}_{5^{-}}$ $\mathrm{MoO}_{3}-\mathrm{TiO}_{2}, \mathrm{TiO}_{2}-\mathrm{SO}_{4}{ }^{2-}, \mathrm{V}_{2} \mathrm{O}_{5}-\mathrm{TiO}_{2}-\mathrm{SO}_{4}{ }^{2-}, \mathrm{MoO}_{3}-\mathrm{TiO}_{2}-\mathrm{SO}_{4}{ }^{2-}$ and $\mathrm{V}_{2} \mathrm{O}_{5}-\mathrm{MoO}_{3}-\mathrm{TiO}_{2}-\mathrm{SO}_{4}{ }^{2-}$ aerogel samples, the appropriate amounts of vanadyl acetylacetonate $\left(\mathrm{V}\left(\mathrm{C}_{5} \mathrm{H}_{7} \mathrm{O}_{2}\right)_{2}\right.$, Fluka, 95 \%) and Molybdenyl acetylacetonate $\left(\mathrm{MoO}_{10} \mathrm{H}_{14} \mathrm{O}_{6}\right.$, Merck Schuchardt), corresponding to theoretical contents $2 \%$ wt. and $6 \%$ wt. of $\mathrm{V}_{2} \mathrm{O}_{5}$ and $\mathrm{MoO}_{3}$, respectively, were introduced in the slurry before the hydrolysis. To obtain the sulfated catalysts, a suitable volume of $\mathrm{H}_{2} \mathrm{SO}_{4}$ solution (Scarlau, 95-97\%), giving a molar ratio $\mathrm{S} / \mathrm{Ti}$ rate $=0.2$, was added to the organic mixture before the hydrolysis step. All the aerogel oxides were calcined for $3 \mathrm{~h}$ at $500{ }^{\circ} \mathrm{C}$ under $\mathrm{O}_{2}$ flow $\left(30 \mathrm{~mL} \cdot \mathrm{min}^{-1}\right)$.

\section{2. Characterization of aerogel catalysts}

\section{2. 1. $\mathrm{N}_{2}$ adsorption-desorption at $77 \mathrm{~K}$}

$\mathrm{N}_{2}$-Physisorption was carried out at $77 \mathrm{~K}$ using a Micromeritics ASAP 2020 apparatus. Prior to $\mathrm{N}_{2}$ adsorption, the samples were degassed at $200{ }^{\circ} \mathrm{C}$ for $6 \mathrm{~h}$. The residual pressure reached during the degassing step was $10^{-5}$ torr.

\section{2. 2. X-ray diffraction (XRD)}


Powder X-ray diffraction measurements were performed on a Brüker AXS D8 diffractometer with CuK $\alpha$ radiation $(\lambda=1.5406 \AA)$. The data of $2 \theta$ were collected from 2 to 80 ${ }^{\circ}$ with a step size of $0.02^{\circ}$. The crystallites size (D) of solids was calculated using the Scherrer formula [38] based on $\mathrm{TiO}_{2}$ anatase specific peak $\left(\sim 2 \theta=25^{\circ}\right): \mathrm{D}=0.89(\lambda / \beta \cos \theta)$

Where, $\lambda$ is the wavelength of $\mathrm{XR}$ radiation, $\beta$ is the corrected peak width at half-maximum intensity (FWHM in radians), and $\theta$ is the peak position of the main reflection

\section{2. 3. Raman spectroscopy}

Raman spectra were collected under ambient conditions in backscattering configuration using a T64000 Jobin-Yvon Spectrometer. The light excitation is provided by the $488 \mathrm{~nm}$ line of an $\mathrm{Ar}^{+}$laser. The incident power is taken equal to $5 \mathrm{~mW}$ at the surface of sample.

\section{2. 4. X-ray Photoelectron Spectroscopy}

XPS experiments were realized with the device ESCALAB 250 of thermo electron with a monochromatic ray $\mathrm{Al} \mathrm{K} \alpha(1486.6 \mathrm{eV})$ as the excitation source. The analyzed surface has a diameter of $400 \mu \mathrm{m}$ and the X-ray Photoelectron spectra are calibrated in binding energy with regard to the binding energy of the $\mathrm{C}-\mathrm{C}$ bond of carbon $\mathrm{C} 1 \mathrm{~s}$ at $284.8 \mathrm{eV}$. The charge is compensated with an electron beam $(-2 \mathrm{eV})$.

\section{2. 5. DRUV-Vis spectroscopy}

Ultraviolet visible diffuse reflectances spectroscopy (DR-UV-vis) was done over the aerogel powder on a PerkinElmer spectrophotometer type instrument lambda 45 coupled to an integration sphere type RSA-PE-20. The UV spectra were recorded in the 200-900 $\mathrm{nm}$ range with a speed of $960 \mathrm{~nm} \mathrm{~min}{ }^{-1}$ and an aperture of $4 \mathrm{~nm}$.

\section{2.6. Temperature Programmed Desorption by Ammonia $\left(\mathrm{NH}_{3}-\mathrm{TPD}\right)$}

The $\mathrm{NH}_{3}$-TPD experiments were performed using an AUTOCHEM 2920 (Micromeritics) equipped with a TCD detector. Prior to $\mathrm{NH}_{3}$ adsorption, the catalyst powder $(\mathrm{m}=0.05 \mathrm{~g})$ was activated under air flow $\left(30 \mathrm{~mL} \mathrm{~min}^{-1}\right)$ at $500{ }^{\circ} \mathrm{C}\left(\operatorname{ramp~} 10^{\circ} \mathrm{C} \mathrm{min}^{-1}\right)$ for 30 
min. After cooling to $100{ }^{\circ} \mathrm{C}$, the sample was saturated with ammonia ( 5 vol\% $\mathrm{NH}_{3}$ in $\mathrm{He}$, flow rate $\left.=30 \mathrm{~mL} \mathrm{~min}^{-1}\right)$ for $45 \mathrm{~min}$. Then, it was flushed with $\mathrm{He}\left(30 \mathrm{~mL} \mathrm{~min}{ }^{-1}\right)$ during $2 \mathrm{~h}$ to remove physisorbed $\mathrm{NH}_{3}$. Finally, the ammonia was desorbed in $\mathrm{He}$ flow $\left(30 \mathrm{~mL} \mathrm{~min}^{-1}\right)$ from $100{ }^{\circ} \mathrm{C}$ to $600{ }^{\circ} \mathrm{C}$ using a heating rate of $10^{\circ} \mathrm{C} \mathrm{min}^{-1}$.

\section{2. 7. Temperature Programmed Reduction by Hydrogen $\left(\mathrm{H}_{2}-\mathrm{TPR}\right)$}

The $\mathrm{H}_{2}$-TPR analyses were realized on a Micromeritics AUTOCHEM 2910 equipped with a TCD detector. Briefly, the aerogel powder $(\mathrm{m}=0.05 \mathrm{~g})$ was pre-treated under $5 \mathrm{vol} \%$ $\mathrm{O}_{2}$ in $\mathrm{He}$ (flow rate $\left.=30 \mathrm{~mL} \mathrm{~min}^{-1}\right)$ at $500{ }^{\circ} \mathrm{C}\left(\operatorname{ramp~} 10^{\circ} \mathrm{C} \mathrm{min}^{-1}\right)$ for $30 \mathrm{~min}$. After being cooled down to $50{ }^{\circ} \mathrm{C}$ in the same atmosphere, the sample was flushed with $\mathrm{He}\left(30 \mathrm{~mL} \mathrm{~min}{ }^{-1}\right)$ then exposed to a flow containing $5 \mathrm{vol} \% \mathrm{H}_{2}$ in $\mathrm{Ar}\left(30 \mathrm{~mL} \mathrm{~min}^{-1}\right)$ and heated between 50 and 800 ${ }^{\circ} \mathrm{C}\left(10{ }^{\circ} \mathrm{C} \min ^{-1}\right)$.

\section{3. NO-SCR catalytic test}

The selective catalytic reduction (SCR) of $\mathrm{NO}$ by $\mathrm{NH}_{3}$ was carried out in a fixed-bed quartz flow reactor operating at atmospheric pressure. The catalyst $(0.05 \mathrm{~g})$ was activated in situ at $200{ }^{\circ} \mathrm{C}$ for 30 min under $\mathrm{O}_{2} / \mathrm{He}\left(20 / 80\right.$, v/v) flow then cooled to $150{ }^{\circ} \mathrm{C}$. A feed gas stream, containing $400 \mathrm{ppm} \mathrm{NO}, 400 \mathrm{ppm} \mathrm{NH}_{3}$ and $8 \% \mathrm{O}_{2}$ in He as a balance gas, was supplied through mass flow controllers to the micro-reactor with a total flow rate of $100 \mathrm{~cm}^{3} \mathrm{~min}^{-1}$ yielding a gas hourly space velocity (GHSV) of $120,000 \mathrm{~h}^{-1}$. The SCR was performed out on programmed temperature from 150 to $500{ }^{\circ} \mathrm{C}$ with the heating rate $6{ }^{\circ} \mathrm{C} \min ^{-1}$. The reactants and products were analyzed by a quadruple mass gas spectrometer (Pfeiffer Omnistar) equipped with Channeltron and Faraday detectors (0-200 amu).

\section{Results and discussion}

\section{1. $\mathrm{N}_{2}$-Adsorption-desorption at $77 \mathrm{~K}$}

Table 1 summarizes the values of specific surface areas $\left(\mathrm{S}_{\mathrm{BET}}\right)$, BJH desorption pore volumes $\left(\mathrm{V}_{\mathrm{PT}}\right)$ and pore size diameters $\left(\Phi_{\text {pore }}\right)$ of samples. As it can be noted, all the aerogel 
materials calcined at $500^{\circ} \mathrm{C}$ exhibit a high surface area $\left(73 \mathrm{~m}^{2} / \mathrm{g} \leq \mathrm{S}_{\mathrm{BET}} \leq 122 \mathrm{~m}^{2} / \mathrm{g}\right)$ and large porosity $\left(0.15 \mathrm{~cm}^{3} / \mathrm{g} \leq \mathrm{V}_{\mathrm{PT}} \leq 0.37 \mathrm{~cm}^{3} / \mathrm{g}\right)$ which reflect their developed texture and good thermal stability. It is worthy to note that, a comparable systems (e.g: $\mathrm{MoO}_{3}(6) / \mathrm{TiO}_{2}$ and $\left.\mathrm{V}_{2} \mathrm{O}_{5}(2.3) \mathrm{MoO}_{3}(6) / \mathrm{TiO}_{2}\right)$ with lower surface area $\left(79.4\right.$ and $64 \mathrm{~m}^{2} / \mathrm{g}$ ) and total pore volume ( 0.28 and $0.27 \mathrm{~cm}^{3} / \mathrm{g}$ ) has been previously obtained by Nova et al. [39] and Lietti et al. [25] via the incipient wetness method. This point out the determining effect of the preparation method on the textural properties of solids and underlines the advantages of the use of aerogel materials as catalytic systems. In fact, it is recognized that large specific surface area implies more active sites exposed on the surface of catalyst and more contact opportunities with gas molecules, which can promote the SCR activity [40].

It should be also mentioned that a partial blockage of $\mathrm{TiO}_{2}$ support's pores by the supported active species seems to be occurred, since a slight decrease of the surface area and pore volume of $\mathrm{TiO}_{2}$ is observed (Table 1) after $\mathrm{V}$, Mo and/or $\mathrm{SO}_{4}{ }^{2-}$ addition [34,41].

Table 1. Textural properties of aerogel catalysts.

\begin{tabular}{lccc}
\hline Sample & $\begin{array}{c}\text { BET surface } \\
\text { area }\left(\mathrm{m}^{2} / \mathrm{g}\right)\end{array}$ & $\begin{array}{c}\text { Total pore } \\
\text { volume }\left(\mathrm{cm}^{3} / \mathrm{g}\right)\end{array}$ & $\begin{array}{c}\text { Average Pore } \\
\text { diameter }\left(\Phi_{\text {pore }}, \AA\right)\end{array}$ \\
\hline $\mathrm{TiO}_{2}$ & 122 & 0.33 & 79 \\
$\mathrm{~V}_{2} \mathrm{O}_{5}-\mathrm{TiO}_{2}$ & 101 & 0.37 & 117 \\
$\mathrm{MoO}_{3}-\mathrm{TiO}_{2}$ & 118 & 0.33 & 87 \\
$\mathrm{~V}_{2} \mathrm{O}_{5}-\mathrm{MoO}_{3}-\mathrm{TiO}_{2}$ & 75 & 0.26 & 116 \\
$\mathrm{TiO}_{2}-\mathrm{SO}_{4}{ }^{2-}$ & 108 & 0.34 & 116 \\
$\mathrm{~V}_{2} \mathrm{O}_{5}-\mathrm{TiO}_{2}-\mathrm{SO}_{4}{ }^{2-}$ & 73 & 0.15 & 62 \\
$\mathrm{MoO}_{3}-\mathrm{TiO}_{2}-\mathrm{SO}_{4}{ }^{2-}$ & 98 & 0.18 & 64 \\
$\mathrm{~V}_{2} \mathrm{O}_{5}-\mathrm{MoO}_{3}-\mathrm{TiO}_{2}-\mathrm{SO}_{4}{ }^{2-}$ & 92 & 0.20 & 71 \\
\hline
\end{tabular}

$\mathrm{N}_{2}$ adsorption-desorption isotherms and pore size distribution curves of aerogel solids are displayed in Fig. 1 and Fig. 2, respectively. The data show that all the samples are 9 
mesoporous materials displaying a type IV isotherm and $\mathrm{H} 1$ or $\mathrm{H} 2$ hysteresis loops, according to the IUPAC classification (Fig. 1)[42]. It is well known that the occurrence of the capillary hysteresis loop depends on the pore sizes. Therefore, the $\mathrm{H} 1$ type, registered for $\mathrm{V}_{2} \mathrm{O}_{5}-\mathrm{TiO}_{2}$ and $\mathrm{V}_{2} \mathrm{O}_{5}-\mathrm{MoO}_{3}-\mathrm{TiO}_{2}$ samples reveals the presence of cylindrical mesoporous channels $[42,43]$. However, $\mathrm{H} 2$ type, observed in the case of $\mathrm{TiO}_{2}, \mathrm{MoO}_{3}-\mathrm{TiO}_{2}, \mathrm{~V}_{2} \mathrm{O}_{5}-\mathrm{TiO}_{2}-\mathrm{SO}_{4}{ }^{2-}, \mathrm{MoO}_{3}-\mathrm{TiO}_{2}-$ $\mathrm{SO}_{4}{ }^{2-}$ and $\mathrm{V}_{2} \mathrm{O}_{5}-\mathrm{MoO}_{3}-\mathrm{TiO}_{2}-\mathrm{SO}_{4}{ }^{2-}$ indicates, in agreement with several previous reports $[41,44-$ 46], the existence of an inkbottle-type pores. Finally, the hysteresis loop obtained over $\mathrm{TiO}_{2}$ $\mathrm{SO}_{4}{ }^{2-}$ cannot be classified into any type of the IUPAC classification and mostly resembles to H3 type conforming to mesoporous solids with a broad distribution of the pores size $[47,48]$. Similar unusual shape of capillary hysteresis loop has been previously registered for $\mathrm{NiCoO}_{2}$ and $\mathrm{Mn} / \mathrm{Ce} / \mathrm{TiW}$ systems and was attributed also to $\mathrm{H} 3$ type $[47,48]$.

The shape of pore size distribution curves presented in Fig 2, confirm the existence of unimodal pore for $\mathrm{TiO}_{2}, \mathrm{MoO}_{3}-\mathrm{TiO}_{2}, \mathrm{~V}_{2} \mathrm{O}_{5}-\mathrm{TiO}_{2}-\mathrm{SO}_{4}{ }^{2-}, \mathrm{MoO}_{3}-\mathrm{TiO}_{2}-\mathrm{SO}_{4}{ }^{2-}, \mathrm{V}_{2} \mathrm{O}_{5}-\mathrm{MoO}_{3}-\mathrm{TiO}_{2}$ and $\mathrm{V}_{2} \mathrm{O}_{5}-\mathrm{MoO}_{3}-\mathrm{TiO}_{2}-\mathrm{SO}_{4}{ }^{2-}$ samples and bimodal pore for $\mathrm{TiO}_{2}-\mathrm{SO}_{4}{ }^{2-}$ catalyst. Noting that the modification of the nature and size of Titania pores, induce by $\mathrm{V}, \mathrm{Mo}$ and/or $\mathrm{SO}_{4}{ }^{2-}$ incorporation (Fig. 2 and Table 1), could provide evidence about the existence of strong interactions between $\mathrm{TiO}_{2}$ and the supported species which affects the textural properties of aerogel catalysts [34]. 

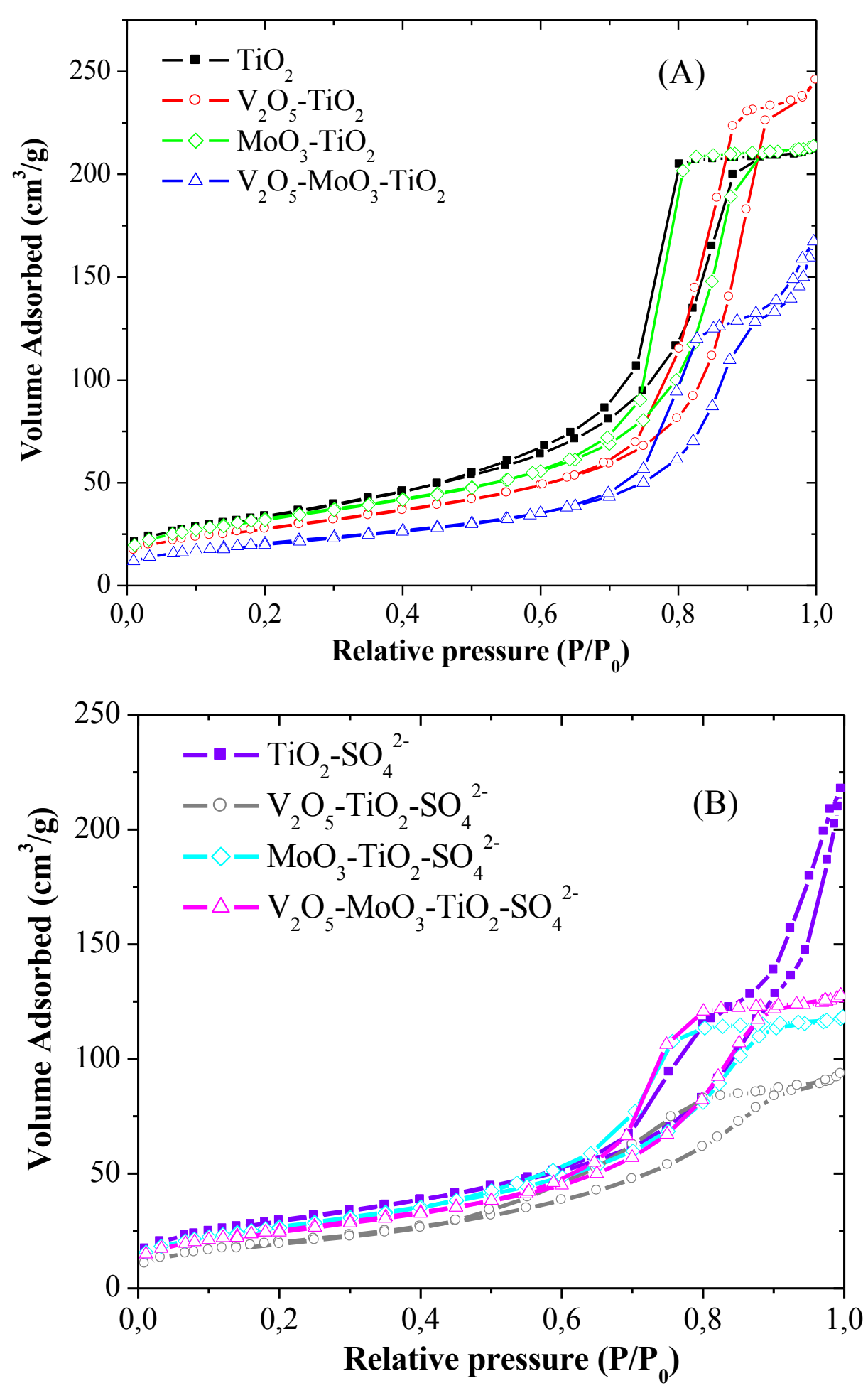

Figure 1. $\mathrm{N}_{2}$ Adsorption-desorption isotherms of nanostructured aerogel catalysts: (A) unsulfated samples and (B) sulfated samples. 

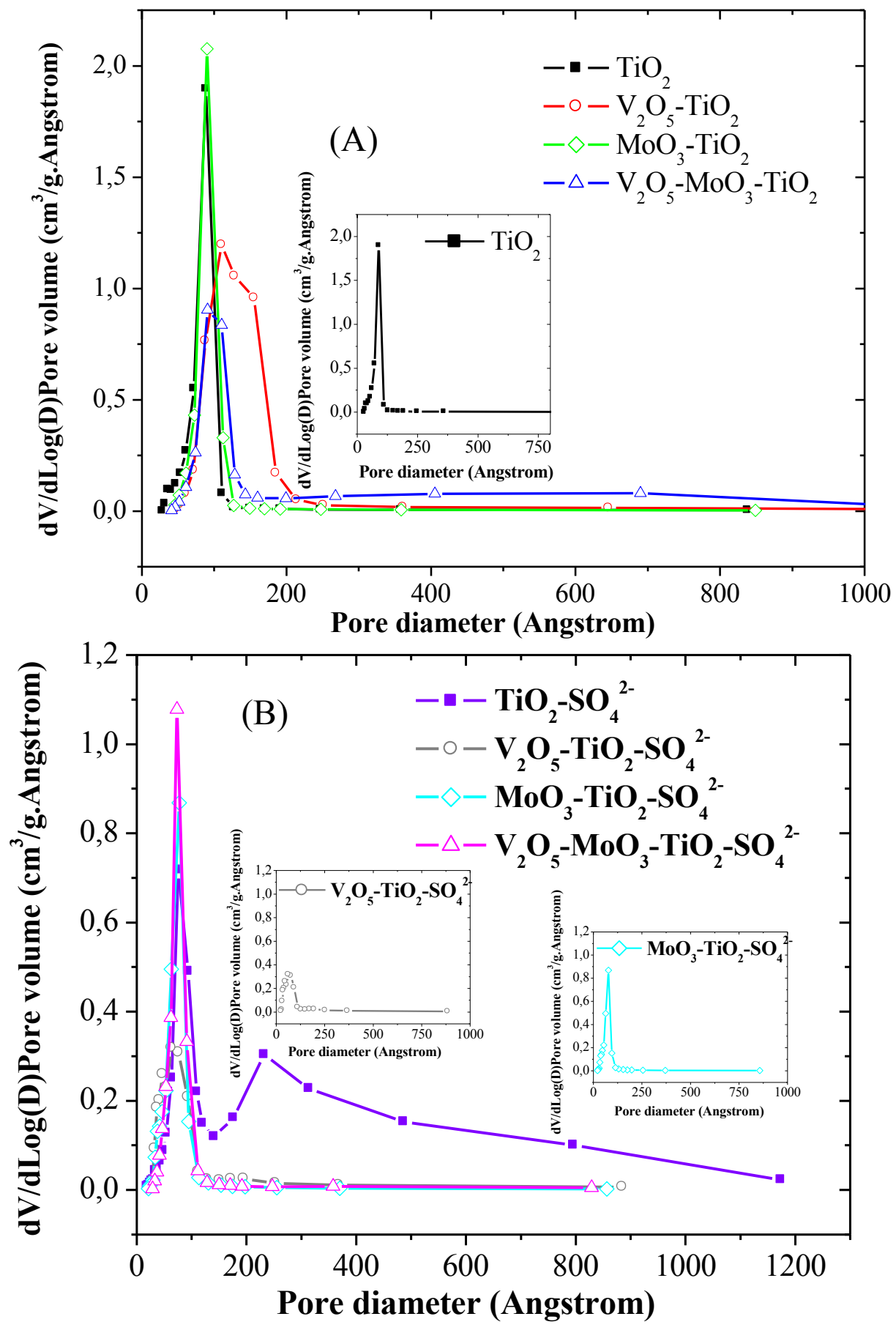

Figure 2. Pore size distribution curves of nanostructured aerogel catalysts: (A) unsulfated samples and (B) sulfated samples 


\section{2. X-ray diffraction}

The XRD patterns of samples are illustrated in Fig. 3. As it can be seen, all the aerogel are well structured materials and show only the typical reflections of $\mathrm{TiO}_{2}$ anatase phase at $2 \theta$ $\approx 25.3^{\circ}(\mathrm{hkl}: 101) ; 36.9^{\circ}(103) ; 37.8^{\circ}(004) ; 38.6^{\circ}(112) ; 48.2^{\circ}(200) ; 53.9^{\circ}(105) ; 55.2^{\circ}$ $(211) ; 62.7^{\circ}(204) ; 69.0^{\circ}(116) ; 70.4^{\circ}(220)$ and $75.2^{\circ}(215)$ [ICSD 01-083-2243]. Additional peaks of very low intensity, corresponding to a trace amount of $\mathrm{TiO}_{2}$ rutile phase [ICSD 01$076-1941]$, are detected at $2 \theta=27.2^{\circ}(110), 35.7^{\circ}(101)$ and $53.9^{\circ}(211)$ in the diffractogram of $\mathrm{V}_{2} \mathrm{O}_{5}-\mathrm{TiO}_{2}$ only. Remarkably, no characteristic peaks of $\mathrm{VO}_{2} ; \mathrm{V}_{2} \mathrm{O}_{5} ; \mathrm{MoO}_{3}$ and $\mathrm{MoO}_{2}$ crystalline phases, principally identified at $2 \theta=27.7^{\circ}(110)$ [ICSD 01-079-1655] ; $2 \theta=20.2^{\circ}$ (001) [ICSD 01-089-2482]; $2 \theta=25.8^{\circ}(210)$ [PDF 00-021-0569] and $2 \theta=26.0^{\circ}(-111)$ [ICSD 01-076-1807], respectively, are perceived for all the catalysts implying the highly dispersion state of $\mathrm{V}$ and $\mathrm{Mo}$ species on the $\mathrm{TiO}_{2}$ surface $[25,28]$. It should be also mentioned that no typical peaks related to $\mathrm{MoS}_{2}$ compound, principally identified at $2 \theta \approx 14.2^{\circ}(002) ; \quad 32.5^{\circ}$ (100) and $39.4^{\circ}$ (103) [JCPDS 37-1492], are seen for the samples containing both Mo and sulfate evidencing that no reaction has been produced between molybdenum and sulfate, during the synthesis or the thermal treatment of catalysts, to form molybdenum disulfide crystalline phase $\left(\mathrm{MoS}_{2}\right)$.

The average crystallites size, which influences the surface areas and subsequently the catalytic performances of samples [49], was estimated based on the strong anatase diffraction peak $\left(101\right.$, at $\left.2 \theta \approx 25^{\circ}\right)$ and the values are listed in table 2 . Noticeably, all the aerogel materials are characterized by a nanometer size ranging between 7.66 and $12.93 \mathrm{~nm}$. This confirms the successful synthesis of a new generation of highly structured nanocatalysts for the NO-SCR reaction. 

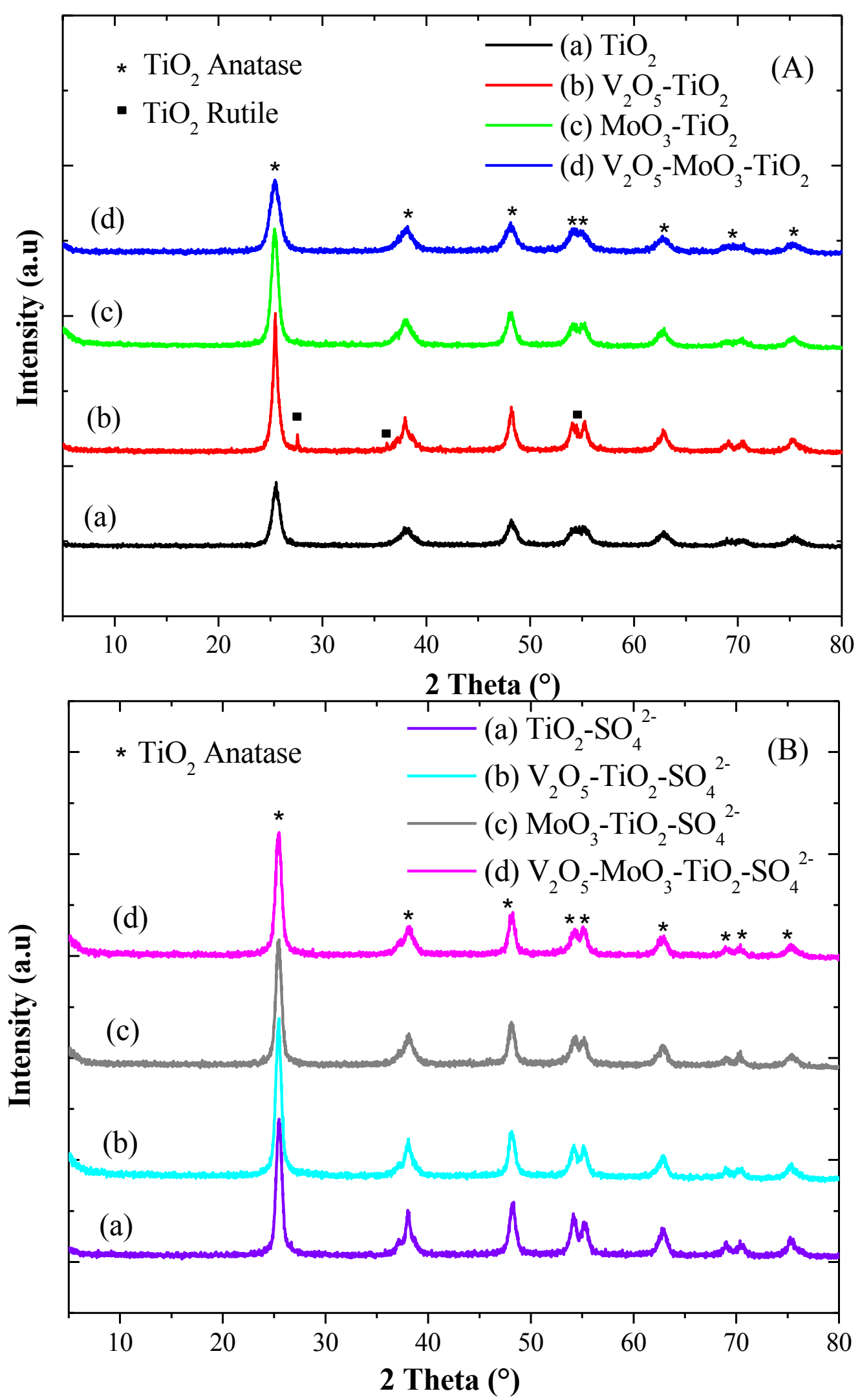

Figure 3. XRD patterns of nanostructured aerogel catalysts: (A) unsulfated samples and (B) sulfated samples. 
Table 2. XRD phases and $\mathrm{TiO}_{2}$ crystallites size of aerogel catalysts.

\begin{tabular}{lccc}
\hline Sample & XRD phases & FWHM $\left(^{\circ}\right)$ & $\begin{array}{c}\mathrm{TiO}_{2} \text { crystallite } \\
\text { size D (nm) }\end{array}$ \\
\hline $\mathrm{TiO}_{2}$ & Anatase & 0.8920 & 8.66 \\
$\mathrm{~V}_{2} \mathrm{O}_{5}-\mathrm{TiO}_{2}$ & Anatase + Rutile $(* \mathrm{t})$ & 0.6259 & 12.41 \\
$\mathrm{MoO}_{3}-\mathrm{TiO}_{2}$ & Anatase & 0.7576 & 10.47 \\
$\mathrm{~V}_{2} \mathrm{O}_{5}-\mathrm{MoO}_{3}-\mathrm{TiO}_{2}$ & Anatase & 1.0356 & 7.66 \\
$\mathrm{TiO}_{2}-\mathrm{SO}_{4}{ }^{2-}$ & Anatase & 0.6160 & 12.93 \\
$\mathrm{~V}_{2} \mathrm{O}_{5}-\mathrm{TiO}_{2}-\mathrm{SO}_{4}{ }^{2-}$ & Anatase & 0.6452 & 12.30 \\
$\mathrm{MoO}_{3}-\mathrm{TiO}_{2}-\mathrm{SO}_{4}{ }^{2-}$ & Anatase & 0.6513 & 12.19 \\
$\mathrm{~V}_{2} \mathrm{O}_{5}-\mathrm{MoO}_{3}-\mathrm{TiO}_{2}-\mathrm{SO}_{4}{ }^{2-}$ & Anatase & 0.7467 & 10.63 \\
\hline
\end{tabular}

With *t $=$ trace amount.

It is established that the controllable regulation of the size and surface features of catalysts, which is possible through a suitable preparation method and synthesis parameters, is an effective way to enhance their catalytic performances [50]. On the other hand, it is recognized that numerous advantages distinguish the sol gel procedure including a simple technology, low process-temperatures and flexible control of the structure and size of final products via many operating parameters [51]. Based on the above XRD and $\mathrm{N}_{2}$ physisorption results, it can be concluded the successful synthesis of new aerogel SCR catalysts with a developed mesoporous texture (high surface area and porosity), nanometer size and good cristallinity of $\mathrm{TiO}_{2}$ anatase phase $(\sim 100 \%)$. This highlights the appropriate choice of both the preparation method (one step sol-gel procedure-supercritical drying) and optimized synthesis conditions (such as: Molar ration Etacac $/ \mathrm{Ti}=1$, and $\mathrm{H}_{2} \mathrm{O} / \mathrm{Ti}=10$, temperature...) for adjusting the physicochemical properties of the final aerogel products.

\section{3. Raman spectroscopy}

Raman spectroscopy has proven to be a valuable tool in elucidating the structure of complex transition metal oxides, presenting either as bulk or two dimensional supported phases. 
Vibrational spectra of solids are presented in Fig. 4. The bands at 145, 197, 396, 515 and 637 $\mathrm{cm}^{-1}$ are observed for all the samples and are assigned to $\mathrm{E}_{\mathrm{g}}, \mathrm{E}_{\mathrm{g}}, \mathrm{B}_{1 \mathrm{~g}}, \mathrm{~A}_{1 \mathrm{~g}}$ and $\mathrm{E}_{\mathrm{g}}$ modes of $\mathrm{TiO}_{2}$ anatase, respectively $[4,34,38,52]$. For the catalysts containing molybdenum, a new weak and broad band is generated at around $950 \mathrm{~cm}^{-1}$ and is attributed to $\mathrm{Mo}=\mathrm{O}$ terminal stretching mode of dispersed molybdenum species $[39,53-54]$. The slightly changes of the terminal $\mathrm{Mo}=\mathrm{O}$ frequency, registered after vanadia or sulfate addition, may serve as a proof about the existence of $\mathrm{V} \leftrightarrow \mathrm{Mo} ; \mathrm{Mo} \leftrightarrow \mathrm{SO}_{4}{ }^{2-}$ and/or $\mathrm{V} \leftrightarrow \mathrm{Mo} \leftrightarrow \mathrm{SO}_{4}{ }^{2-}$ interactions which probably modify the structure and/or the polymerization degree of Mo surface species. Many researchers have studied by Raman spectroscopy the relationship between the terminal $\mathrm{Mo}=\mathrm{O}$ frequency and the state of Mo species dispersed on several supports [53-54]. W. Yu et al. [54] demonstrated that the isolated tetrahedral molybdena gradually changes into the octahedral polymolybdate species and the terminal $\mathrm{Mo}=\mathrm{O}$ stretching frequency shifts from 921 to $964 \mathrm{~cm}^{-1}$ when molybdena loadings increases from 0.2 to $0.8 \mathrm{mmol} / 100 \mathrm{~m}^{2} \mathrm{CeO}_{2}$ on $\mathrm{MoO}_{3} / \mathrm{CeO}_{2}$ systems. Accordingly, the octahedral polymeric molybdena species seem to be the major form in the case of our samples. Noting that the terminal $\mathrm{Mo}=\mathrm{O}$ vibration is hardly detectable in the $\mathrm{V}_{2} \mathrm{O}_{5}-\mathrm{MoO}_{3}-\mathrm{TiO}_{2}-$ $\mathrm{SO}_{4}{ }^{2-}$ Raman spectrum. This may be due to its very low intensity since a visible decrease in the Raman peaks intensity of $\mathrm{TiO}_{2}$ is seen in the case of $\mathrm{V}_{2} \mathrm{O}_{5}-\mathrm{MoO}_{3}-\mathrm{TiO}_{2}-\mathrm{SO}_{4}{ }^{2-}$ and $\mathrm{V}_{2} \mathrm{O}_{5}-\mathrm{TiO}_{2}-$ $\mathrm{SO}_{4}{ }^{2-}$ catalysts. This decrease has been already observed for many supported metal oxides $\left(\mathrm{V}_{2} \mathrm{O}_{5} / \mathrm{TiO}_{2}, \mathrm{MoO}_{3} / \mathrm{TiO}_{2}, \mathrm{SiO}_{2} / \mathrm{TiO}_{2}, \mathrm{Cu} / \mathrm{TiO}_{2}\right.$ and $\mathrm{V}_{2} \mathrm{O}_{5}-\mathrm{MoO}_{3} / \mathrm{TiO}_{2}$ [25]) and it was explained by three different factors: increase disorder of the surface, increase absorption of the excitation radiation and more complex solid-state phenomena [25].

As shown also in Fig. 4, no typical Raman bands related to crystalline phases of $\mathrm{V}_{2} \mathrm{O}_{5}$ $\left(994 \mathrm{~cm}^{-1}[55,56]\right)$ and $\mathrm{MoO}_{3}\left(818,995 \mathrm{~cm}^{-1}[25,54]\right)$ are detected for all the aerogel samples suggesting, in line with the XRD results and in perfect agreement with the results already 
obtained by Lietti et al.[25] for similar SCR systems, the highly dispersed state of vanadium and molybdenum on the catalysts surface. In addition, no typical bands of well dispersed $\mathrm{VO}_{\mathrm{x}}$ species (between 800 and $1050 \mathrm{~cm}^{-1}$ [25]) are found in the Raman spectra of our samples most probably due to the low loading of vanadium $[34,57,58]$. The absence of $\mathrm{VO}_{\mathrm{x}}$ characteristic peaks on the Raman spectra of several V-based catalysts (like: $\mathrm{V}_{2} \mathrm{O}_{5}-\mathrm{CeO}_{2}-\mathrm{TiO}_{2}-\mathrm{SO}_{4}{ }^{2-}$ [34], $\mathrm{V}_{2} \mathrm{O}_{5} / \mathrm{CeO}_{2}$ [57], $\mathrm{V}_{2} \mathrm{O}_{5} / \mathrm{TiO}_{2}$ and $\mathrm{V}_{2} \mathrm{O}_{5} / \mathrm{TiO}_{2}-\mathrm{SO}_{4}{ }^{2-}$ [58], VTS and VTCeS [59]) has been already remarked and explained by the low quantities of vanadium. 

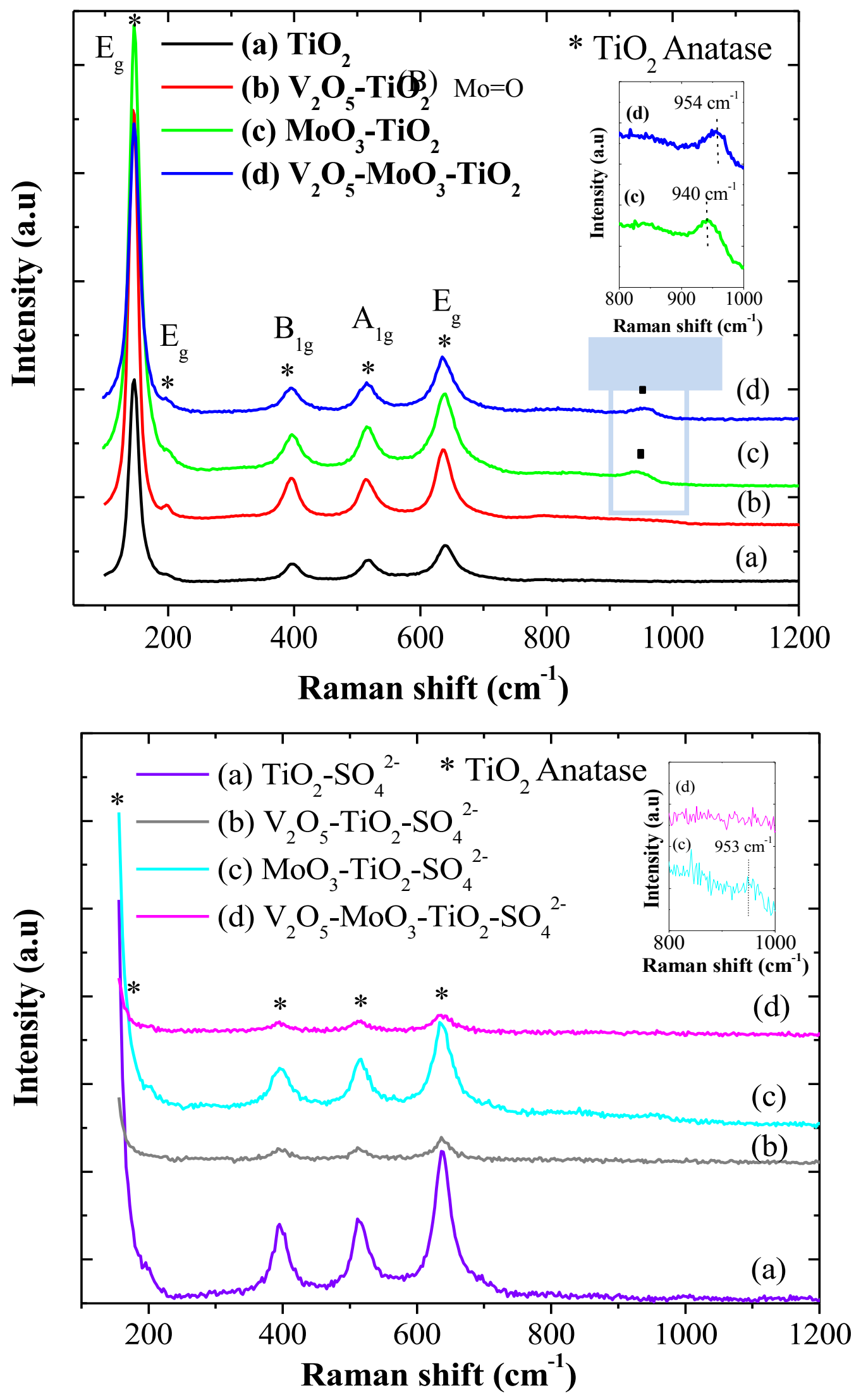

Figure 4. Raman spectra of nanostructured aerogel catalysts: (A) unsulfated samples and (B) sulfated samples. 


\section{4. X-ray photoelectron spectroscopy}

The XPS analysis was exclusively applied to the new $\mathrm{V}_{2} \mathrm{O}_{5}-\mathrm{MoO}_{3}-\mathrm{TiO}_{2}-\mathrm{SO}_{4}{ }^{2-}$ catalyst to provide information about the surface interaction and chemical state of active elements at the surface. The XPS spectra of Ti, O, Mo, V and S are depicted in Fig. 5.

The Ti $2 \mathrm{p} 3 / 2$ and Ti $2 p 1 / 2$ binding energy, corresponding to the typical $\mathrm{Ti}^{4+}$ oxidation state in a tetragonal structure [60], are detected at 459.1 and $464.8 \mathrm{eV}$, respectively, in the $\mathrm{Ti}$ 2 XPS spectra (Fig. 5 a). These values are slightly higher compared to those characterizing pure $\mathrm{TiO}_{2}(458.1$ and $463.8 \mathrm{eV})$ [61] due to strong interactions developed between the $\mathrm{TiO}_{2}$ support and active species (V, Mo and/or $\left.\mathrm{SO}_{4}{ }^{2-}\right)[34,60,61]$.

Two peaks are detected in the XPS spectra of O1s (Fig. 5b): the first peak, centred at $530.2 \mathrm{eV}$, could be assigned to the lattice oxygen $\mathrm{O}^{2-}$ (reference as $\mathrm{O} \beta$ ) [62] and the second one, maximizing at $531.8 \mathrm{eV}$, can be ascribed to several $\mathrm{O} 1 \mathrm{~s}$ states of surface adsorbed oxygen (referenced as $\mathrm{O} \alpha$ ) $[60,62,63]$. It was considered that $\mathrm{O} \alpha$ is beneficial to oxidize $\mathrm{NO}$ to $\mathrm{NO}_{2}$ which could improve the $\mathrm{DeNO}_{\mathrm{x}}$ activity at low temperatures [64].

According to the literature, the binding energies of oxidation states of Mo are: 235.85 and $232.65 \mathrm{eV}$ for $\mathrm{MoO}_{3} ; 234.9$ and $231.7 \mathrm{eV}$ for $\mathrm{Mo}_{2} \mathrm{O}_{5}$ and 232.3, $229.1 \mathrm{eV}$ for $\mathrm{MoO}_{2}$ [65]. The XPS spectra of Mo3d (Fig 5c) shows principally two peaks centred at around 235.4 and $232.4 \mathrm{eV}$ which can be essentially ascribed to $\mathrm{Mo}^{6+}$ state (Mo $3 \mathrm{~d}_{3 / 2}$ and Mo $3 \mathrm{~d}_{5 / 2}$, respectively). This suggests that molybdenum mainly exists at its highest oxidation state $(+6)$ on the $\mathrm{V}_{2} \mathrm{O}_{5^{-}}$ $\mathrm{MoO}_{3}-\mathrm{TiO}_{2}-\mathrm{SO}_{4}{ }^{2-}$ surface.

The intense peak centered at $515.6 \mathrm{eV}$ in the V 2p3/2 XPS spectrum (Fig. $5 \mathrm{~d}$ ), is assigned to $\mathrm{V}^{4+}$ surface species [34,66], whereas, the weak shoulder localized at around 517.8 $\mathrm{eV}$ is linked to $\mathrm{V}^{5+}$ species $[34,66]$. Similar results, indicating the stabilization of vanadium at 
its $4+$ oxidation state and suggesting the existence of $\mathrm{V} \leftrightarrow \mathrm{SO}_{4}{ }^{2-}$ has been obtained in a previous work [34].

An asymmetric peak with bending energies of $169.0 \mathrm{eV}$ were measured for the $\mathrm{S} 2 \mathrm{p}$ line (Fig. 5 e). According to similar previous data [55,61-68], these binding energy are typical of $\mathrm{S}^{6+}$ oxidation state in the $-\mathrm{SO}_{4}{ }^{2-}$ groups. The $\mathrm{S}^{6+}$ species might be present in the form of bidentate sulfate on the surface of $\mathrm{TiO}_{2}$, either chelating or bridging, as proposed in the literature $[67,68]$. Nevertheless, no peaks attributable to sulfide (at 161-162.8 eV) and elemental sulfur (at 164 eV) $[55,68]$ are detected confirming, in line with the XRD results, that no molybdenum sulfide $\left(\mathrm{MoS}_{2}\right)$ is formed on the $\mathrm{V}_{2} \mathrm{O}_{5}-\mathrm{MoO}_{3}-\mathrm{TiO}_{2}-\mathrm{SO}_{4}{ }^{2-}$ surface.

It is worth mentioning that the presence of highly dispersed vanadium and sulfate species on the $\mathrm{V}_{2} \mathrm{O}_{5}-\mathrm{MoO}_{3}-\mathrm{TiO}_{2}-\mathrm{SO}_{4}{ }^{2-}$ surface, which was not proven by Raman technique, is evidenced by using XPS analysis. This point out the importance to use several consistent technique for the structure examination of catalysts. 

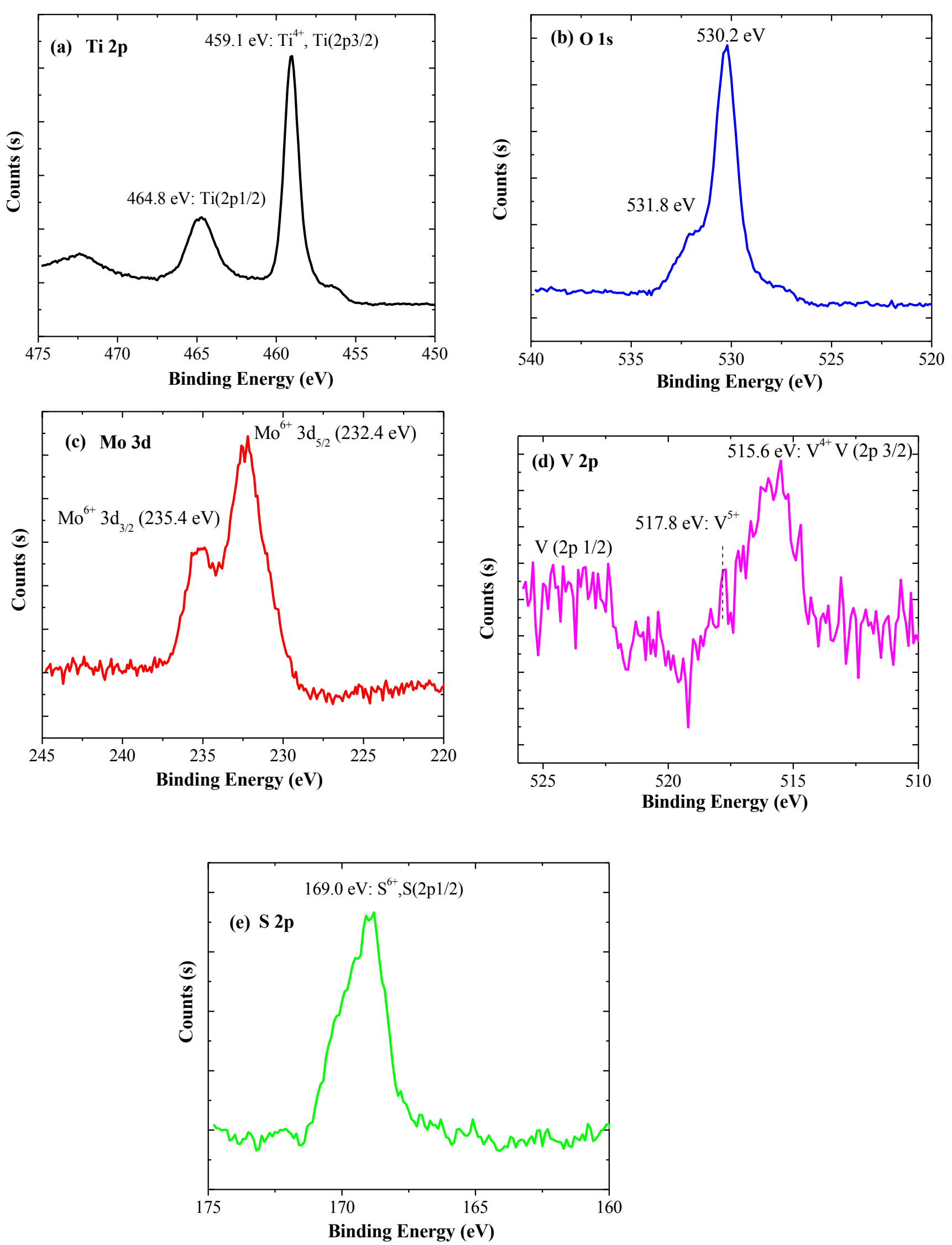

Figure 5. XPS results over the novel $\mathrm{V}_{2} \mathrm{O}_{5}-\mathrm{MoO}_{3}-\mathrm{TiO}_{2}-\mathrm{SO}_{4}{ }^{2-}$ nanostructured aerogel catalyst. 


\section{5. DR UV-vis spectroscopy}

To discern the chemical state and obtain more information regarding the dispersion of $\mathrm{V}$ and Mo species at the catalysts surface, diffuse reflectance UV-vis spectra of samples are showed in Fig. 6. The spectrum of all the aerogel materials (Fig. 6 A) shows a broad absorption band in 200-400 nm range which is related to $\mathrm{O}^{2-} \rightarrow \mathrm{M}^{\mathrm{n}+}$ charge transfer transitions $(\mathrm{M}=\mathrm{Ti}$; V; Mo), corresponding to the excitation of electrons from the valence band (having the $\mathrm{O} 2 \mathrm{p}$ character) to the conduction band (having the Ti 3d, V 3d and/or Mo 3d character) [69]. The presence of this band identify the anatase phase of $\mathrm{TiO}_{2}$ and can reveal the presence of highly dispersed V and Mo species on its surface [34,/69-75]. Additional peaks have appeared in 350$400 \mathrm{~nm}$ range for the catalysts containing vanadium and/or molybdenum and can be associated with $\mathrm{O}^{2-} \rightarrow \mathrm{V}^{5+}$ and $\mathrm{O}^{2-} \rightarrow \mathrm{Mo}^{5+}$ charge transfer $(\mathrm{CT})$ transitions in a new types of $\mathrm{VO}_{\mathrm{x}}$ and $\mathrm{MoO}_{\mathrm{x}}$ surface species, respectively $[34,70,76,77]$. For clearness purposes, the attribution of $\mathrm{Ti}$, V and Mo characteristic bands, based on the literature, is stated in Table 3.

This literature report (Table 3) shows that there is a significant overlap of spectral regions of the investigated elements. Therefore, on the basis of UV-absorption bands, it can be supposed the coexistence of a variety of highly dispersed vanadium and molybdenum species on the $\mathrm{TiO}_{2}$ surface.

Noting that the decrease of the intensity of band located at around $378-385 \mathrm{~nm}$, most probably related to $\mathrm{Mo}^{5+} \mathrm{CT}$ transition [77], after sulfate addition (Fig. 6B), could demonstrates (in line with the XPS result) the predominance of $\mathrm{Mo}^{6+}$ species on the surface of sulfated systems like $\mathrm{V}_{2} \mathrm{O}_{5}-\mathrm{MoO}_{3}-\mathrm{TiO}_{2}-\mathrm{SO}_{4}{ }^{2-}$. The weak broad bands situated at around 600 and 665 $\mathrm{nm}$ can be ascribed to $\mathrm{Mo}^{5+}$ and $\mathrm{V}^{4+} \mathrm{d}-\mathrm{d}$ transitions, respectively [78-80], while, the shoulders localized at $\sim 320$ and $520 \mathrm{~nm}$, more visible in the case of unsulfated samples, could be 
attributed to $\mathrm{MoO}_{3}$ [74] and $\mathrm{V}_{2} \mathrm{O}_{5}$ [78] crystalline phases, respectively which exist in a trace amounts and seem to be too small to be detected by the XRD technique.
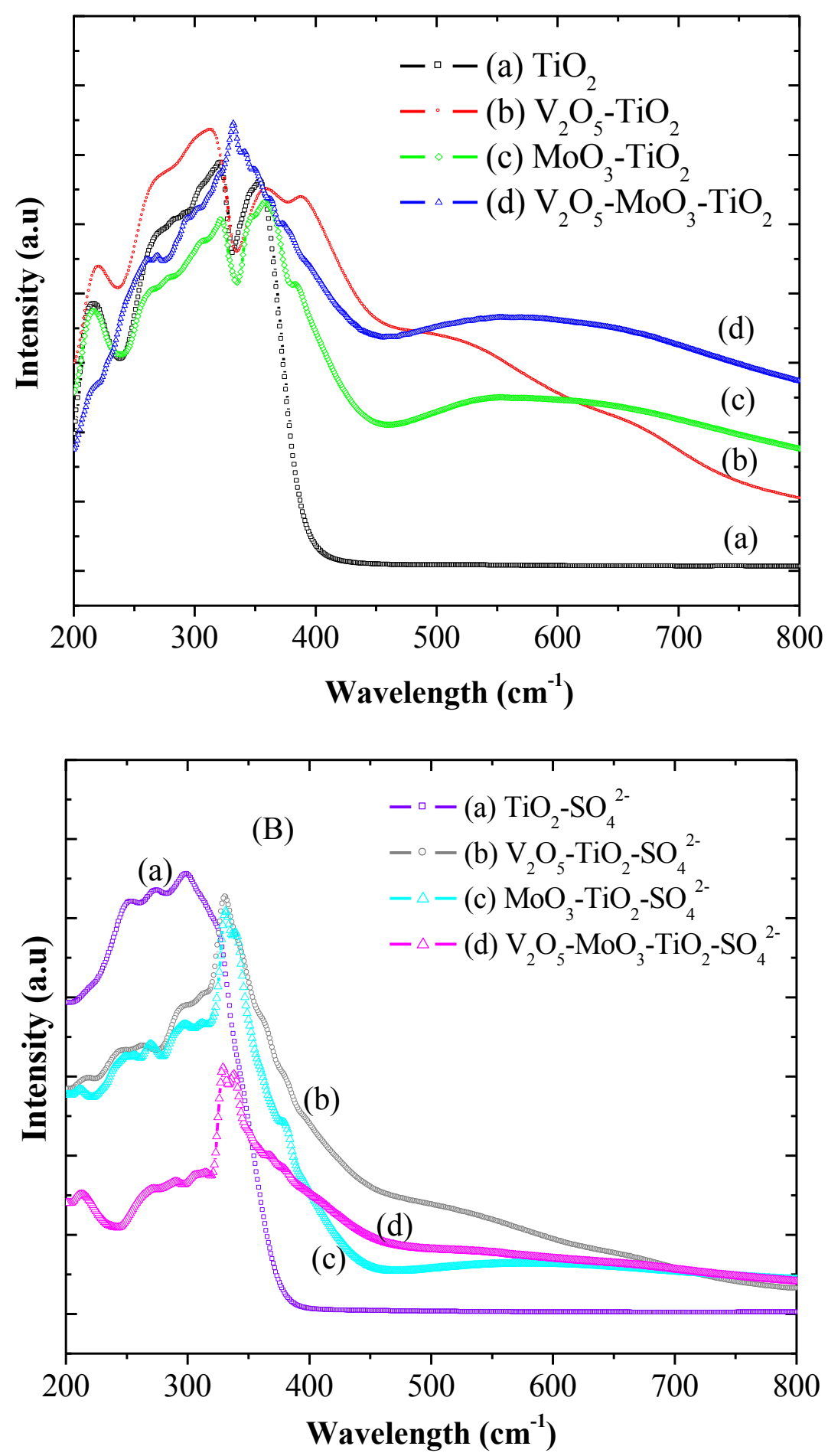

Figure 6. DRUV-Vis spectra of nanostructured aerogel catalysts: (A) unsulfated samples and (B) sulfated samples. 
Table 3. UV-vis diffuse reflectance band positions and assignments found in the literature for M species $(\mathrm{M}=\mathrm{Ti}, \mathrm{V}$ and $\mathrm{Mo})$.

\begin{tabular}{|c|c|c|c|c|}
\hline Species & $\begin{array}{l}\text { DRUV-vis band } \\
\text { Position: } \lambda(\mathrm{nm})\end{array}$ & Type of transition & Assignments & Ref. \\
\hline \multirow[t]{3}{*}{$\mathrm{Ti}$} & 217 & $\mathrm{O}^{2-} \rightarrow \mathrm{Ti}^{4+} \mathrm{LMCT}$ & Tetrahedral $\mathrm{Ti}^{4+}$ species & {$[34,70]$} \\
\hline & 275 & $\mathrm{O}^{2-} \rightarrow \mathrm{Ti}^{4+} \mathrm{LMCT}$ & Octahedral $\mathrm{Ti}^{4+}$ species & {$[34,70]$} \\
\hline & 320 and 350 & $\mathrm{O}^{2-} \rightarrow \mathrm{Ti}^{4+} \mathrm{LMCT}$ & $\mathrm{TiO}_{2}$ Anatase phase & {$[34,70]$} \\
\hline \multirow[t]{7}{*}{$\mathrm{V}$} & $240-280$ & $\mathrm{O}^{2-} \rightarrow \mathrm{V}^{4+} \mathrm{LMCT}$ & $\begin{array}{l}\text { Monomeric tetrahedral } \\
\mathrm{V}^{4+} \text { species }\end{array}$ & {$[34,71]$} \\
\hline & $280-340$ & $\mathrm{O}^{2-} \rightarrow \mathrm{V}^{5+} \mathrm{LMCT}$ & $\begin{array}{l}\text { Monomeric tetrahedral } \mathrm{V}^{5+} \\
\text { species }\end{array}$ & {$[34,71]$} \\
\hline & $350-400$ & $\mathrm{O}^{2-} \rightarrow \mathrm{V}^{5+} \mathrm{LMCT}$ & $\begin{array}{l}\text { Oligomeric tetrahedral } \mathrm{VO}_{\mathrm{x}} \\
\text { chain }\end{array}$ & {$[34,76]$} \\
\hline & & & $\begin{array}{l}\text { Low polymeric tertahedral } \\
\mathrm{VO}_{\mathrm{x}} \text { chain }\end{array}$ & {$[34,70]$} \\
\hline & & & $\begin{array}{l}\mathrm{V} \text { in square pyramidal } \\
\text { configuration }\end{array}$ & {$[34,70]$} \\
\hline & $500-550$ & LMCT & Crystalline $\mathrm{V}_{2} \mathrm{O}_{5}$ & {$[78]$} \\
\hline & $545-800$ & d-d transition & Vanadium (IV) & {$[78]$} \\
\hline \multirow[t]{7}{*}{ Mo } & $200-270$ & $\mathrm{O}^{2-} \rightarrow \mathrm{Mo}^{6+} \mathrm{LMCT}$ & Isolated tetrahedral $\mathrm{Mo}^{6+}$ & {$[72-75]$} \\
\hline & $260-280$ & $\mathrm{O}^{2-} \rightarrow \mathrm{Mo}^{6+} \mathrm{LMCT}$ & Polymeric octahedral $\mathrm{Mo}^{6+}$ & [73-75] \\
\hline & $300-350$ & & & \\
\hline & $360-385$ & $\mathrm{O}^{2-} \rightarrow \mathrm{Mo}^{5+} \mathrm{LMCT}$ & - & {$[77]$} \\
\hline & 320 & - & Crystalline $\mathrm{MoO}_{3}$ & {$[74]$} \\
\hline & $400-900$ & d-d transition & Molybdenum (V) & {$[79,80]$} \\
\hline & $600-750$ & & & \\
\hline
\end{tabular}

3. 6. $\mathrm{H}_{2}-\mathrm{TPR}$ and $\mathrm{NH}_{3}-\mathrm{TPD}$ analysis

The acid and redox properties of catalyst play a crucial role in the $\mathrm{DeNO}_{\mathrm{x}}$ process $[11,18,81,82]$. It was recognized that the SCR activity is governed, at low temperature by the reducibility of catalyst, and by its acidity at high temperature [82].

$\mathrm{H}_{2}$-TPR analysis was carried out to investigate the redox properties of aerogel oxides. The obtained $\mathrm{H}_{2}$-TPR profiles are illustrated in Fig. 7. As it is well known, $\mathrm{TiO}_{2}$ support is 
characterized by a very low reducibility [68] which was confirmed in this work by the very weak $\mathrm{H}_{2}$ consumption peak detected at around $540{ }^{\circ} \mathrm{C}$ in its $\mathrm{H}_{2}$-TPR profile (Fig. 7 A). The addition of vanadium, molybdenum and/or sulfate influences differently the redox properties of aerogel catalysts. In fact, two unresolved peaks maximizing at 430 and $500{ }^{\circ} \mathrm{C}$ are observed for the binary $\mathrm{V}_{2} \mathrm{O}_{5}-\mathrm{TiO}_{2}$ and are associated with the reduction of highly dispersed $\mathrm{VO}_{\mathrm{x}}$ species $[34,62]$. Two well resolved peaks are detected also in the case of $\mathrm{MoO}_{3}-\mathrm{TiO}_{2}$ system; the low temperature hydrogen consumption $\left(\sim 401{ }^{\circ} \mathrm{C}\right)$ is assigned to the first-step reduction of polymeric octahedral Mo species (weakly bounded to the support) from $\mathrm{Mo}^{6+}$ to $\mathrm{Mo}^{4+}[75,83]$. However, the peak at higher temperature $\left(\sim 717^{\circ} \mathrm{C}\right)$ is ascribed to the second-step reduction, from $\mathrm{Mo}^{4+}$ to $\mathrm{Mo}^{0}$, of polymeric octahedral Mo species with different aggregation degree and to the reduction of highly dispersed tetrahedral $\mathrm{Mo}^{6+}$ species, in strong interaction with the support $[75,83]$.

The $\mathrm{V}_{2} \mathrm{O}_{5}-\mathrm{MoO}_{3}-\mathrm{TiO}_{2}$ ternary catalyst displays different reduction behaviour if compared to corresponding binary samples $\left(\mathrm{V}_{2} \mathrm{O}_{5}-\mathrm{TiO}_{2}\right.$ and $\left.\mathrm{MoO}_{3}-\mathrm{TiO}_{2}\right)$, since a several peaks centred at around $380,450,523,727$ and $756{ }^{\circ} \mathrm{C}$ are detected and could be attributed to the reduction of $\mathrm{V}$ and Mo species, toward different temperatures reduction with respect to binary systems. This observation may serve as a proof about the existence of strong interaction between vanadium and molybdenum $(\mathrm{V} \leftrightarrow \mathrm{Mo})$ which probably affects the nature, dispersion and/or polymerization degree of $\mathrm{V}$ and Mo co-supported species and, thus, influences the reducibility of ternary catalyst.

Fig. $7 \mathrm{~B}$ shows a twin peaks at 627 and $653{ }^{\circ} \mathrm{C}$ in the $\mathrm{H}_{2}-\mathrm{TPR}$ profile of $\mathrm{TiO}_{2}-\mathrm{SO}_{4}{ }^{2-}$ support which correspond to the reduction of $\mathrm{SO}_{4}{ }^{2-}$ groups $[35,58,84]$. The reduction of $\mathrm{SO}_{4}{ }^{2-}$ anions is moved to lower temperature and completely hides both the reduction of vanadium and the first reduction peak of molybdenum for all the sulfated catalysts. In addition, a decrease in 
the intensity and temperature reduction of the second $\mathrm{H}_{2}$ consumption peak of Mo is noted in the $\mathrm{H}_{2}$-TPR profile of $\mathrm{MoO}_{3}-\mathrm{TiO}_{2}-\mathrm{SO}_{4}{ }^{2-}$ (from 717 to $676^{\circ} \mathrm{C}$ ), while, this peak has completely disappeared for $\mathrm{V}_{2} \mathrm{O}_{5}-\mathrm{MoO}_{3}-\mathrm{TiO}_{2}-\mathrm{SO}_{4}{ }^{2-}$ catalyst. This can be correlated with the existence of diverse interactions between sulfate ions and the supported transition metals $\left(\mathrm{V} \leftrightarrow \mathrm{SO}_{4}{ }^{2-}\right.$, $\mathrm{Mo} \leftrightarrow \mathrm{SO}_{4}{ }^{2-}$ and $\mathrm{V} \leftrightarrow \mathrm{SO}_{4}{ }^{2-} \leftrightarrow \mathrm{Mo}$ ) which make easy the sulfate reduction and influence the reducibility of Mo and V species. Accordingly, it can be suggested that these interactions modify the nature, coordination, polymerization degree, dispersion and/or oxidation state of the supported transition metals and, consequently, affect the redox properties of the aerogel mixed oxides. 

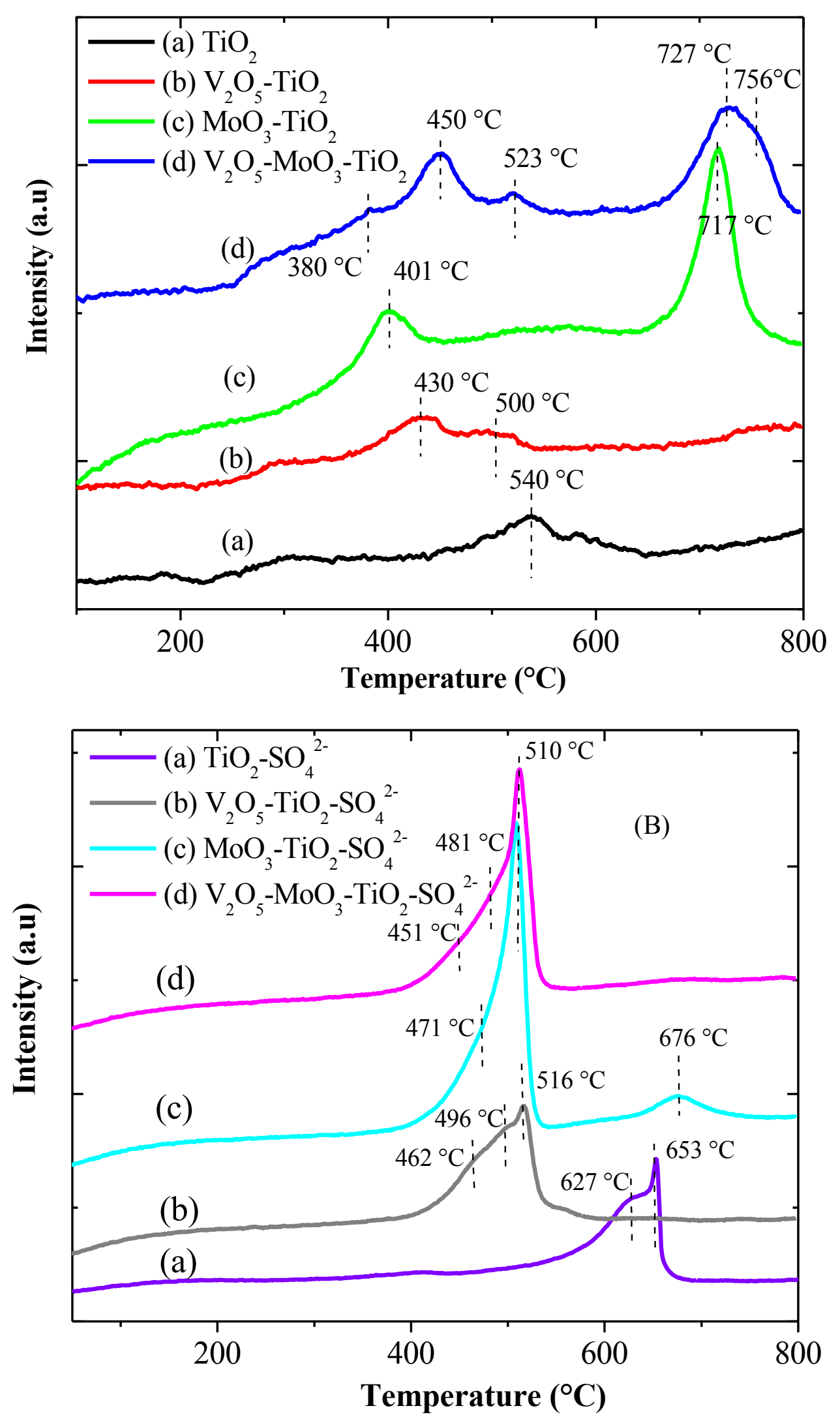

Figure 7. $\mathrm{H}_{2}$-TPR profiles of the nanostructured aerogel catalysts: (A) unsulfated samples and (B) sulfated samples. 
In the $\mathrm{NH}_{3}-\mathrm{SCR}$ reaction, it is important to adsorb and activate $\mathrm{NH}_{3}$ reductant on the catalyst surface. Adsorption and desorption of $\mathrm{NH}_{3}$ molecules are greatly influenced by the acidic properties of catalysts which control their reactivity in the NO-SCR reaction, especially at high temperature [82]. The surface acidity of aerogel samples was examined via the temperature programmed desorption of ammonia and the obtained $\mathrm{NH}_{3}$-TPD profiles are given in Fig. 8. For all the unsulfated catalysts (Fig. 8 A), two broad peaks with different intensities are recorded: the first one, located in the $100-250{ }^{\circ} \mathrm{C}$ temperature range, is attributed to ammonia desorption from weak acid sites and the second one, situated in the $250-450{ }^{\circ} \mathrm{C}$ temperature range, corresponds to desorbed ammonia from medium strong acid sites $[34,69]$. It is known that that $\mathrm{NH}_{3}$ adsorbs as ammonia coordinatively held over Lewis acid sites and as ammonium ions produced by protonation of ammonia at Brønsted sites. According to P. Forzatti et al. [86], vanadyls $(\mathrm{V}=\mathrm{O})$ and molybdenyls $(\mathrm{Mo}=\mathrm{O})$ act as adsorption sites for ammonia, $\mathrm{Ti}^{4+}$ could also coordinate ammonia. The authors reported that the $\mathrm{NH}_{3}$ coordinated at Lewis sites is associated with Ti, V and Mo oxide surface species, but, Brønsted acid sites are absent on the surface of pure titania and can be generated from $\mathrm{V}-\mathrm{OH}$ and $\mathrm{Mo-OH}$ groups [86].

Beside the former peaks, a new well resolved peak is appeared at higher temperatures $\left(>450{ }^{\circ} \mathrm{C}\right.$ ) in the $\mathrm{NH}_{3}$-TPD profiles of the sulfated samples (Fig. 8 B) indicative of the creation of a new type of strong acid sites at the catalysts surface, by the presence of sulfate groups. This result is consistent with that obtained in our previous work for $\mathrm{V}_{2} \mathrm{O}_{5}-\mathrm{CeO}_{2}-\mathrm{TiO}_{2}-\mathrm{SO}_{4}{ }^{2-}$ aerogel catalyst [34]. The positive effect of sulfate groups on the acidity and, thus, on the SCR activity of various catalysts has been also reported by Z. Si et al. [37], R. Khodayari et al. [87] and J. P. Chen et al. [88]. Noticeably, the temperature of new $\mathrm{NH}_{3}$ desorption peak, which is strongly influenced by the acid sites strength, is affected by the chemical composition of samples and 
decreases following this order: $520{ }^{\circ} \mathrm{C}\left(\mathrm{TiO}_{2}-\mathrm{SO}_{4}{ }^{2-}\right), 500{ }^{\circ} \mathrm{C}\left(\mathrm{MoO}_{3}-\mathrm{TiO}_{2}-\mathrm{SO}_{4}{ }^{2-}\right), 490{ }^{\circ} \mathrm{C}\left(\mathrm{V}_{2} \mathrm{O}_{5^{-}}\right.$ $\left.\mathrm{TiO}_{2}-\mathrm{SO}_{4}{ }^{2-}\right)$ and $470{ }^{\circ} \mathrm{C}\left(\mathrm{V}_{2} \mathrm{O}_{5}-\mathrm{MoO}_{3}-\mathrm{TiO}_{2}-\mathrm{SO}_{4}{ }^{2-}\right)$. This confirms the existence of strong interactions between the supported transition metals and sulfate groups. Depending on the nature of element present in the sample, these interactions modify not only the redox properties of the aerogel solids (as verified by $\mathrm{H}_{2}$-TPR analysis) but also the strength and most probably the nature of surface acid sites. Markedly, a higher total acidity, in the $100-500{ }^{\circ} \mathrm{C}$ temperature range, is obtained in the case of new $\mathrm{V}_{2} \mathrm{O}_{5}-\mathrm{MoO}_{3}-\mathrm{TiO}_{2}-\mathrm{SO}_{4}{ }^{2-}$ aerogel catalyst. 

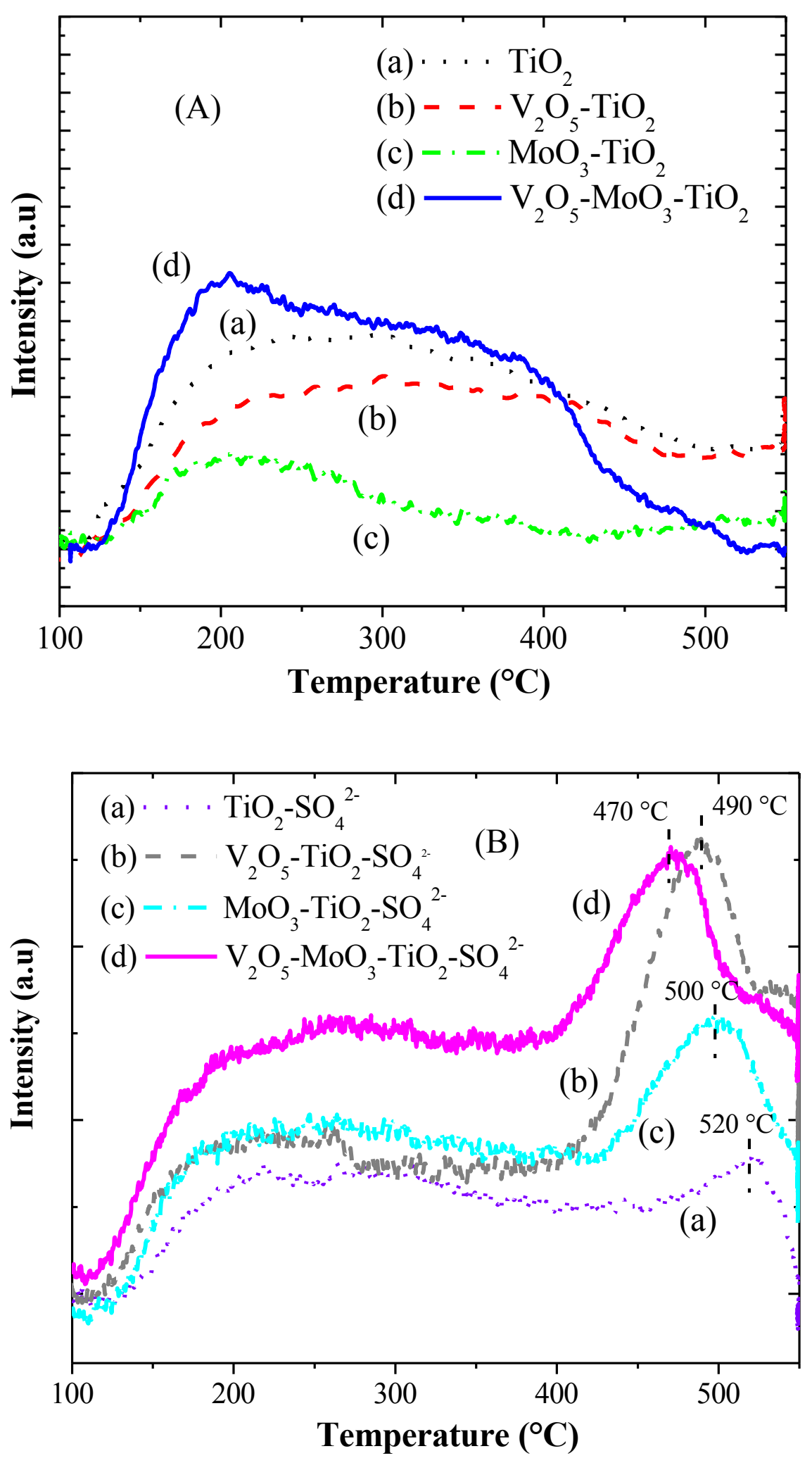

Figure 8. $\mathrm{NH}_{3}$-TPD profiles of nanostructured aerogel catalysts: (A) unsulfated samples and (B) sulfated samples 


\section{7. Catalytic test}

The curves of the NO conversion as a function of temperature, over the unsulfated aerogel catalysts, are depicted in Fig. 9 A. It is clearly seen that $\mathrm{TiO}_{2}$ support exhibits a low NO conversion. The addition of vanadium, molybdenum or both of them increases the SCR activity, especially at low temperature: around $0,10,28$ and $77 \%$ of NO conversions are achieved at $300{ }^{\circ} \mathrm{C}$ over $\mathrm{TiO}_{2}, \mathrm{MoO}_{3}-\mathrm{TiO}_{2}, \mathrm{~V}_{2} \mathrm{O}_{5}-\mathrm{TiO}_{2}$ and $\mathrm{V}_{2} \mathrm{O}_{5}-\mathrm{MoO}_{3}-\mathrm{TiO}_{2}$ samples, respectively. This underlines the crucial role of redox sites created by molybdenum $\left(\mathrm{Mo}^{6+} / \mathrm{Mo}^{5+}\right)$ and, particularly, by vanadium $\left(\mathrm{V}^{5+} / \mathrm{V}^{4+}\right)$ on the $\mathrm{MoO}_{3}-\mathrm{TiO}_{2}, \mathrm{~V}_{2} \mathrm{O}_{5}-\mathrm{TiO}_{2}$ and $\mathrm{V}_{2} \mathrm{O}_{5}-\mathrm{MoO}_{3}-\mathrm{TiO}_{2}$ surface for the low temperature $\mathrm{NH}_{3}-\mathrm{SCR}$ reaction. Noticeably, the reactivity of the ternary catalyst $\left(\mathrm{V}_{2} \mathrm{O}_{5}-\mathrm{MoO}_{3}-\right.$ $\mathrm{TiO}_{2}$ ) is significantly higher than that of corresponding binary systems; In fact, the reaction temperature window is extended and shifted towards lower temperatures over this ternary catalyst: around 3,9 and $30 \%$ of $\mathrm{NO}$ conversions are reached at $250{ }^{\circ} \mathrm{C}$ using $\mathrm{MoO}_{3}-\mathrm{TiO}_{2}$, $\mathrm{V}_{2} \mathrm{O}_{5}-\mathrm{TiO}_{2}$ and $\mathrm{V}_{2} \mathrm{O}_{5}-\mathrm{MoO}_{3}-\mathrm{TiO}_{2}$, respectively. This result is in perfect agreement with those already obtained by L. Lietti et al. [25,26] and D. W. Know et al. [29] for VMoTi systems prepared by the impregnation method. It indicates that the co-existence of vanadium and molybdenum species and most likely the interactions developed between them, which affect the reducibility and surface acidity of $\mathrm{V}_{2} \mathrm{O}_{5}-\mathrm{MoO}_{3}-\mathrm{TiO}_{2}$ catalyst, play a key role in improving the reactivity of $\mathrm{V}$ and Mo active sites (acid and redox ones) and lead to more active catalyst for $\mathrm{DeNO}_{\mathrm{x}}$ ing at low temperatures. At high temperature, $\mathrm{NO}$ conversion and $\mathrm{N}_{2}$ selectivity decrease over $\mathrm{V}_{2} \mathrm{O}_{5}-\mathrm{TiO}_{2}$ and $\mathrm{V}_{2} \mathrm{O}_{5}-\mathrm{MoO}_{3}-\mathrm{TiO}_{2}$ catalysts due to the secondary reaction of $\mathrm{NH}_{3}$ oxidation. The NO conversion does not exceed $75 \%$, in the $400-500{ }^{\circ} \mathrm{C}$ temperature range, over all the unsulfated catalysts. 

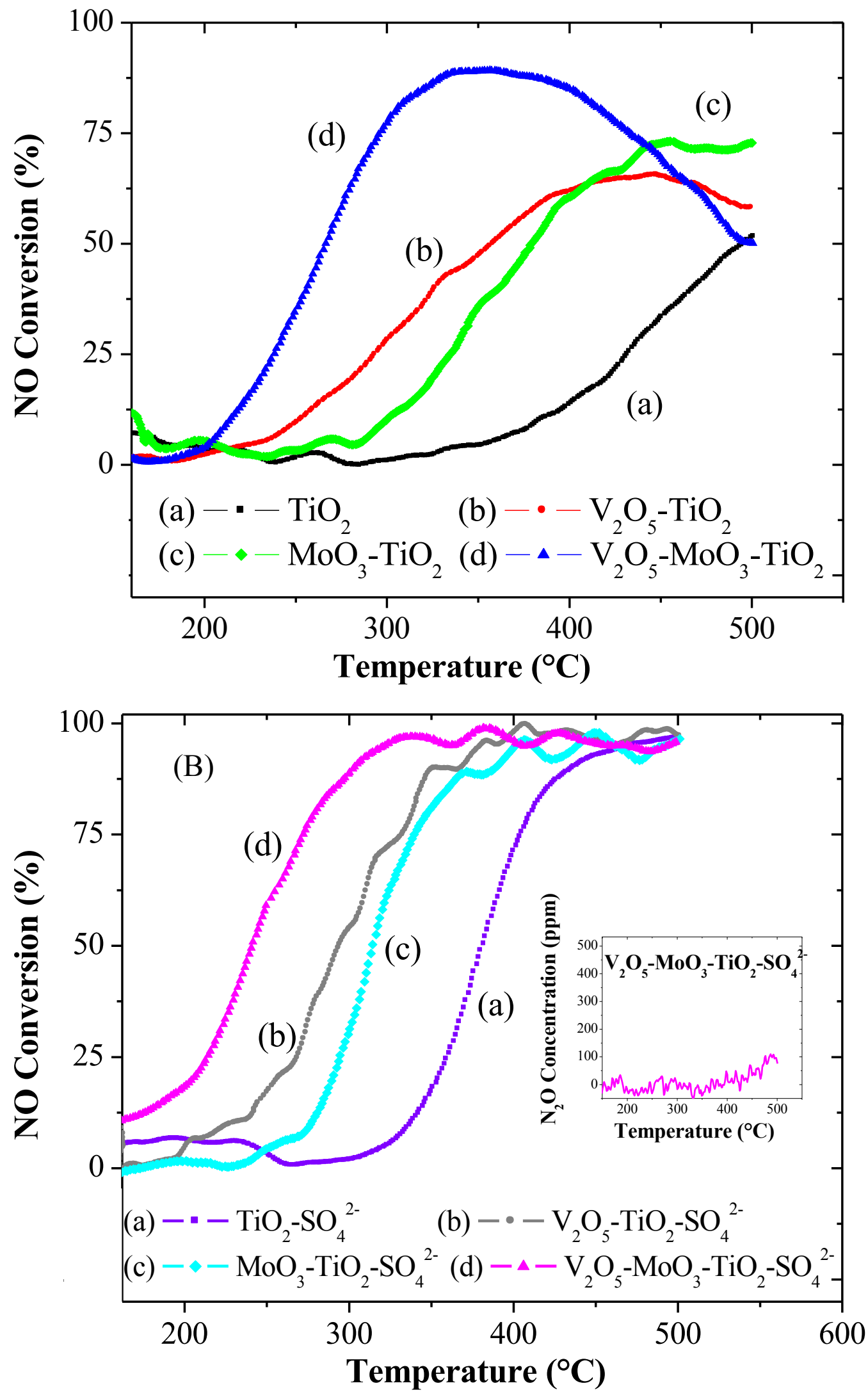
The addition of $\mathrm{SO}_{4}{ }^{2-}$ groups enhances both $\mathrm{NO}$ conversion and $\mathrm{N}_{2}$ selectivity at high temperature $\left(>350^{\circ} \mathrm{C}\right)$ leading to more active and $\mathrm{N}_{2}$ selective catalysts with respect to sulfate free ones (Fig. 9B). Interestingly, more than $90 \%$ of NO conversions are achieved in the 435$500{ }^{\circ} \mathrm{C}, 390-500{ }^{\circ} \mathrm{C}$ and $350-500{ }^{\circ} \mathrm{C}$ temperature ranges over $\mathrm{TiO}_{2}-\mathrm{SO}_{4}{ }^{2-}, \mathrm{MoO}_{3}-\mathrm{TiO}_{2}-\mathrm{SO}_{4}{ }^{2-}$ and $\mathrm{V}_{2} \mathrm{O}_{5}-\mathrm{TiO}_{2}-\mathrm{SO}_{4}{ }^{2-}$ catalysts, respectively. More interestingly, the best SCR activity on the whole temperature range $\left(150-500{ }^{\circ} \mathrm{C}\right)$ is obtained over the sulfated ternary sample $\left(\mathrm{V}_{2} \mathrm{O}_{5^{-}}\right.$ $\left.\mathrm{MoO}_{3}-\mathrm{TiO}_{2}-\mathrm{SO}_{4}{ }^{2-}\right)$. Using this new aerogel catalyst, around $60 \%$ and more than $90 \%$ of NO conversions, with a high $\mathrm{N}_{2}$ selectivity (between 75 and $100 \%$ ), are achieved at $250{ }^{\circ} \mathrm{C}$ and in the range of $300-500{ }^{\circ} \mathrm{C}$, respectively (Table 4). The increase of the high temperature SCR activity by sulfating the catalysts is in perfect agreement with the most reports existing in the literature [34,35-37,89-91]. It is obviously linked to the enhancement of the surface acidity and acid sites reactivity of catalysts by (i) the presence of sulfate groups and (ii) the interactions developed between the $\mathrm{SO}_{4}{ }^{2-}$ ions and the supported active species.

For the SCR reaction, it is recognized that both acidity and redox properties of catalysts are the key factors governing its reactivity $[11,81,82]$. Accordingly, it can be suggested that the simultaneous presence of $\mathrm{V}$, Mo and sulfate allows a good balance between the actives redox and acid sites leading to an excellent new catalyst $\left(\mathrm{V}_{2} \mathrm{O}_{5}-\mathrm{MoO}_{3}-\mathrm{TiO}_{2}-\mathrm{SO}_{4}{ }^{2-}\right)$ for DeNOxing in a wide temperature range $\left(150-500{ }^{\circ} \mathrm{C}\right)$. The reactivity of these active sites seems to be improved by divers interactions developed between the supported species (like V↔Mo, $\mathrm{V} \leftrightarrow \mathrm{SO}_{4}{ }^{2-}, \mathrm{Mo} \leftrightarrow \mathrm{SO}_{4}{ }^{2-}$ and $\left.\mathrm{V} \leftrightarrow \mathrm{SO}_{4}{ }^{2-} \leftrightarrow \mathrm{Mo}\right)$. A synergism in the SCR reaction, related to the existence of V-Mo and $\mathrm{V}-\mathrm{W}$ electronic interactions has been reported earlier for $\mathrm{V}_{2} \mathrm{O}_{5^{-}}$ $\mathrm{MoO}_{3} / \mathrm{TiO}_{2}$ and $\mathrm{V}_{2} \mathrm{O}_{5}-\mathrm{WO}_{3} / \mathrm{TiO}_{2}$ systems $[26,92,93]$. Recently, X. Hu et al. [7] concluded that a synergistic effect between $\mathrm{Mn}$ and Mo species might exist in the $\mathrm{NH}_{3}$-SCR reaction using $\mathrm{Mo}(\mathrm{x})-\mathrm{MnO}_{\mathrm{x}}$ nanorods. 
Table 4. Catalytic performances of $\mathrm{V}_{2} \mathrm{O}_{5}-\mathrm{MoO}_{3}-\mathrm{TiO}_{2}-\mathrm{SO}_{4}{ }^{2-}$ nanostructured aerogel catalyst calcined at $500{ }^{\circ} \mathrm{C}$ in NO-SCR by $\mathrm{NH}_{3}:[\mathrm{NO}]=\left[\mathrm{NH}_{3}\right]=0.04 \%,\left[\mathrm{O}_{2}\right]=8.00 \%$ balance with He and $(G H S V)=120000 \mathrm{~h}^{-1}$.

\begin{tabular}{cccccc}
\hline Aerogel catalyst & $\begin{array}{c}\text { Temperature } \\
\left({ }^{\circ} \mathrm{C}\right)\end{array}$ & $\begin{array}{c}\text { NO Conversion } \\
(\%)\end{array}$ & \multicolumn{3}{c}{$\begin{array}{c}\text { Selectivity } \\
(\%)\end{array}$} \\
& & & $\mathrm{N}_{2}$ & $\mathrm{~N}_{2} \mathrm{O}$ & $\mathrm{NO}_{2}$ \\
\hline $\mathrm{V}_{2} \mathrm{O}_{5}-\mathrm{MoO}_{3}-\mathrm{TiO}_{2}-\mathrm{SO}_{4}{ }^{2-}$ & 200 & 18.7 & 100 & 0 & 0 \\
& 250 & 59.1 & 100 & 0 & 0 \\
300 & 89.0 & 100 & 0 & 0 \\
350 & 96.4 & 100 & 0 & 0 \\
400 & 96.3 & 96 & 4 & 0 \\
450 & 95.4 & 88 & 12 & 0 \\
500 & 95.8 & 75 & 25 & 0 \\
\hline
\end{tabular}

As it can be seen in Fig. 10, compared to $\mathrm{V}_{2} \mathrm{O}_{5}-\mathrm{WO}_{3} / \mathrm{TiO}_{2}$ commercial catalyst (EUROCAT containing 3.15 wt $\% \mathrm{~V}_{2} \mathrm{O}_{5}, 9$ wt $\% \mathrm{WO}_{3}, 6.5 \mathrm{wt} \% \mathrm{SiO}_{2}, 1.5 \mathrm{wt} \% \mathrm{Al}_{2} \mathrm{O}_{3}, 1$ wt \% $\mathrm{CaO}, 0.85$ wt $\% \mathrm{SO}_{4}{ }^{2-}$ and $78 \mathrm{wt} \% \mathrm{TiO}_{2}$ [94]), and under the same experimental conditions $\left([\mathrm{NO}]=\left[\mathrm{NH}_{3}\right]=400 \mathrm{ppm}\right)$, the new $\mathrm{V}_{2} \mathrm{O}_{5}-\mathrm{MoO}_{3}-\mathrm{TiO}_{2}-\mathrm{SO}_{4}{ }^{2-}$ aerogel catalyst demonstrates a similar SCR activity, in the $200-375{ }^{\circ} \mathrm{C}$ temperature range, but exhibits a superior catalytic performances at higher temperature $\left(375-500{ }^{\circ} \mathrm{C}\right)$. After adding water $\left(3.5 \% \mathrm{H}_{2} \mathrm{O}\right)$ in the reaction gas mixture, the NO conversion over the two catalysts slightly decreases, especially at low temperatures $\left(<350{ }^{\circ} \mathrm{C}\right)$ for the aerogel $\mathrm{V}_{2} \mathrm{O}_{5}-\mathrm{MoO}_{3}-\mathrm{TiO}_{2-} \mathrm{SO}_{4}{ }^{2-}$. At high temperatures $(>$ $400{ }^{\circ} \mathrm{C}$ ), the new aerogel system shows a better resistance to water vapour than the $\mathrm{V}_{2} \mathrm{O}_{5^{-}}$ $\mathrm{WO}_{3} / \mathrm{TiO}_{2}$ commercial one which in turn demonstrates a higher resistance to water vapour at lower temperature $\left(<400{ }^{\circ} \mathrm{C}\right)$. 


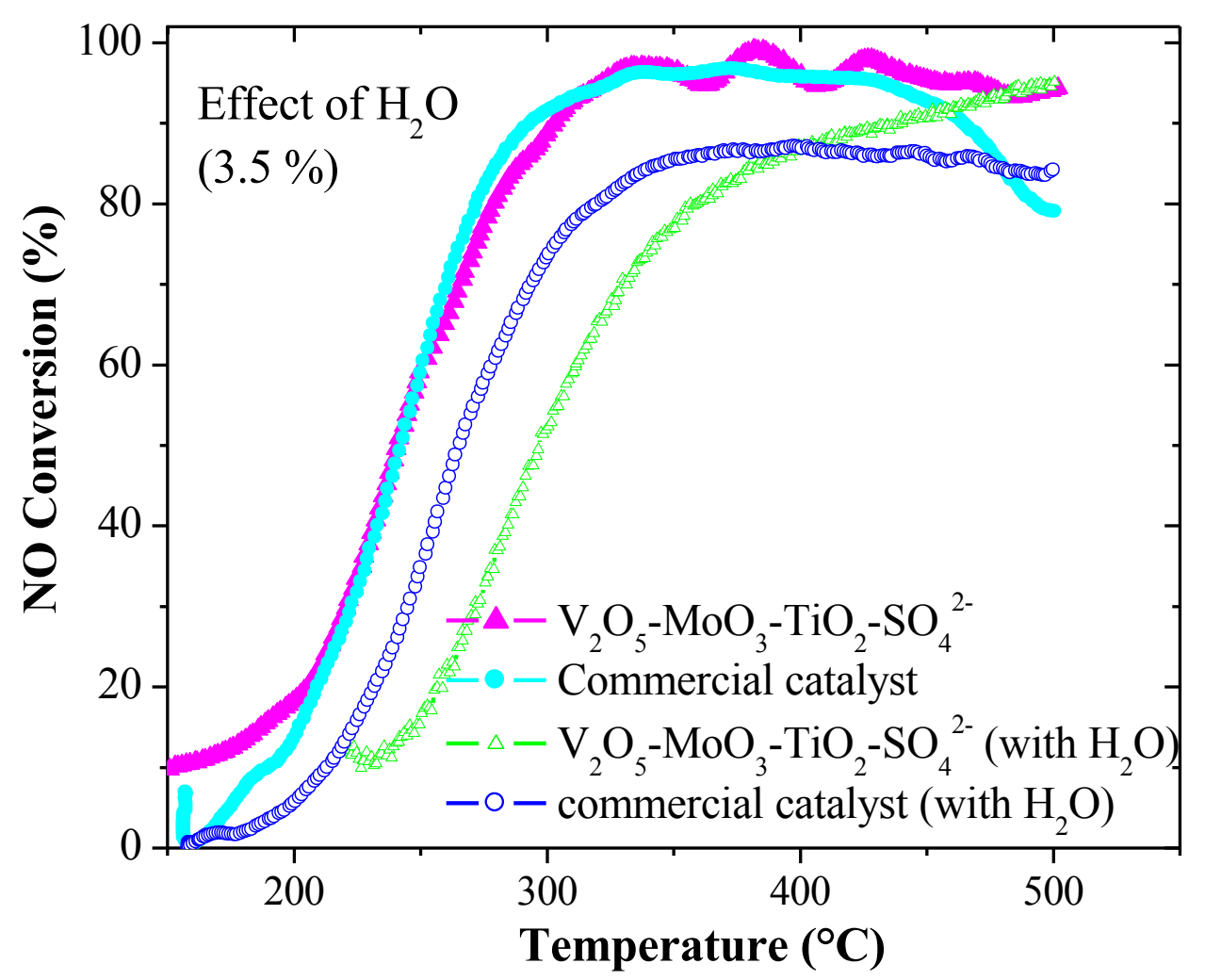

Figure 10. NO conversion versus reaction temperature over $\mathrm{V}_{2} \mathrm{O}_{5}-\mathrm{MoO}_{3}-\mathrm{TiO}_{2}-\mathrm{SO}_{4}{ }^{2-}$ aerogel catalyst and $\mathrm{V}_{2} \mathrm{O}_{5}-\mathrm{WO}_{3} / \mathrm{TiO}_{2}$ commercial one, $[\mathrm{NO}]=\left[\mathrm{NH}_{3}\right]=0.04 \% ;\left[\mathrm{O}_{2}\right]=8.00 \%$ and balance with $\mathrm{He},(\mathrm{GHSV})=120000 \mathrm{~h}^{-1}$, without $\mathrm{H}_{2} \mathrm{O}$ and with $3.5 \% \mathrm{H}_{2} \mathrm{O}$.

The effect of the NO concentration (400 and $1000 \mathrm{ppm}$ ) on the SCR activity of new $\mathrm{V}_{2} \mathrm{O}_{5}-\mathrm{MoO}_{3}-\mathrm{TiO}_{2-} \mathrm{SO}_{4}{ }^{2-}$ aerogel catalyst, in the presence of water $\left(3.5 \% \mathrm{H}_{2} \mathrm{O}\right)$, was investigated and the results are represented in Fig. 11. Noticeably, using a mixture containing $400 \mathrm{ppm}$ NO and $400 \mathrm{ppm} \mathrm{NH}_{3}$, a high $\mathrm{NO}$ conversions ( $\geq 88 \%$ ) are obtained, in the $400-500{ }^{\circ} \mathrm{C}$ temperature range, over the $\mathrm{V}_{2} \mathrm{O}_{5}-\mathrm{MoO}_{3}-\mathrm{TiO}_{2}-\mathrm{SO}_{4}{ }^{2-}$ aerogel catalyst. The NO-SCR activity is clearly improved at high temperature by increasing the NO concentration. Surprisingly, $100 \%$ NO conversion with $100 \% \mathrm{~N}_{2}$ selectivity are achieved, in the $450-500{ }^{\circ} \mathrm{C}$ temperature range, when the NO-SCR reaction was carried out using the concentrations $[\mathrm{NO}]=\left[\mathrm{NH}_{3}\right]=1000 \mathrm{ppm}$ (Table 5). 


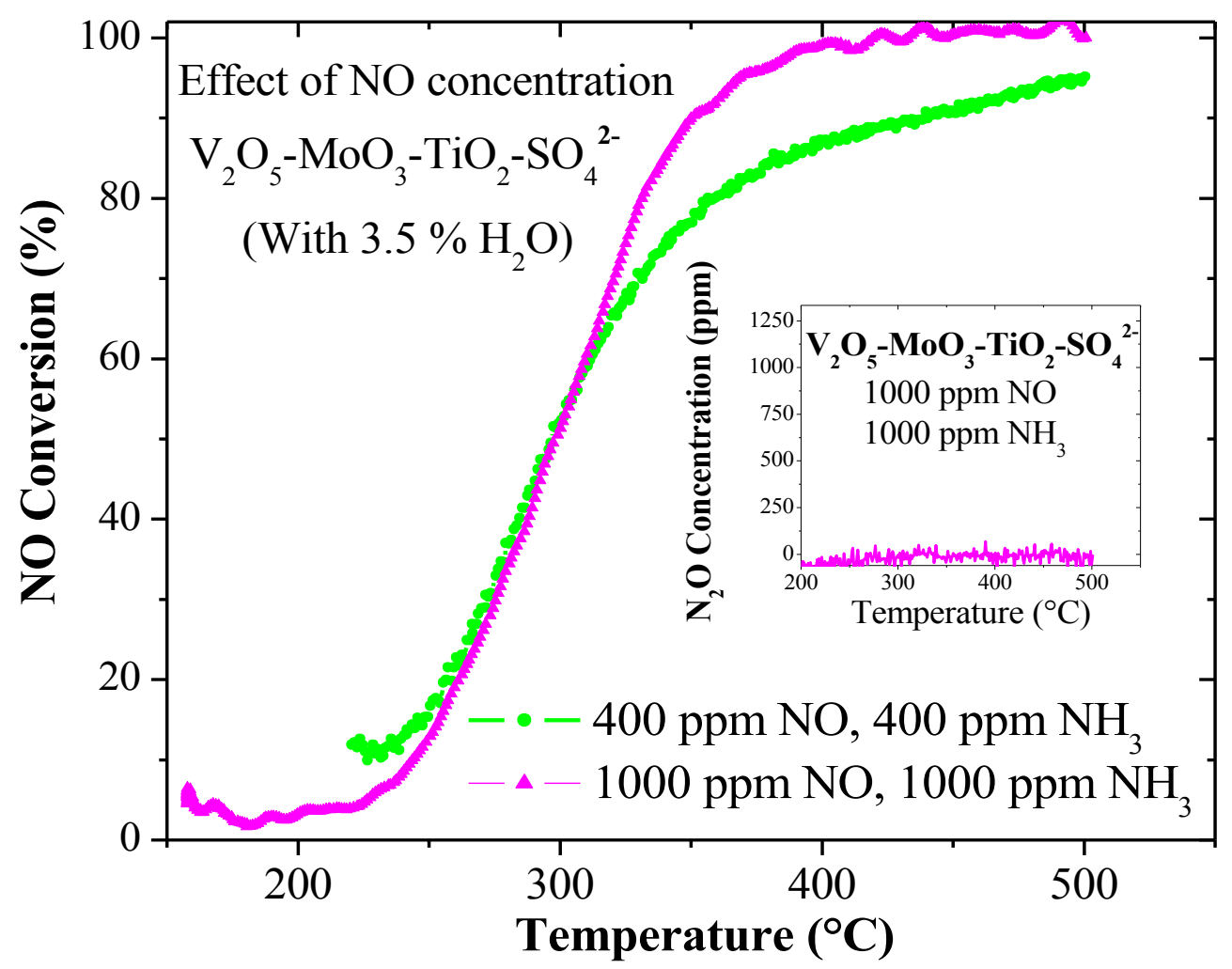

Figure 11. Effect of $\mathrm{NO}$ concentration $(0.04$ or $0.1 \%)$ on the SCR activity of $\mathrm{V}_{2} \mathrm{O}_{5}-\mathrm{MoO}_{3}$ $\mathrm{TiO}_{2}-\mathrm{SO}_{4}{ }^{2-}$ aerogel catalyst, $[\mathrm{NO}]=\left[\mathrm{NH}_{3}\right]=0.04$ or $0.1 \%,\left[\mathrm{O}_{2}\right]=8.00 \%$ and balance with $\mathrm{He}, 3.5 \% \mathrm{H}_{2} \mathrm{O},(\mathrm{GHSV})=120000 \mathrm{~h}^{-1}$. 
Table 5. Catalytic performances of $\mathrm{V}_{2} \mathrm{O}_{5}-\mathrm{MoO}_{3}-\mathrm{TiO}_{2}-\mathrm{SO}_{4}{ }^{2-}$ nanostructured aerogel catalyst calcined at $500{ }^{\circ} \mathrm{C}$ in $\mathrm{NH}_{3}-\mathrm{SCR}$ of $\mathrm{NO}:[\mathrm{NO}]=\left[\mathrm{NH}_{3}\right]=0.1 \%,\left[\mathrm{O}_{2}\right]=8.00 \%$ balance with $\mathrm{He}$, $3.5 \% \mathrm{H}_{2} \mathrm{O}$ and $(\mathrm{GHSV})=120000 \mathrm{~h}^{-1}$.

\begin{tabular}{cccccc}
\hline Aerogel catalyst & $\begin{array}{c}\text { Temperature } \\
\left({ }^{\circ} \mathrm{C}\right)\end{array}$ & \multicolumn{2}{c}{$\begin{array}{c}\text { NO Conversion } \\
(\%)\end{array}$} & \multicolumn{3}{c}{$\begin{array}{c}\text { Selectivity } \\
(\%)\end{array}$} \\
& & & $\mathrm{N}_{2}$ & $\mathrm{~N}_{2} \mathrm{O}$ & $\mathrm{NO}_{2}$ \\
\hline $\mathrm{V}_{2} \mathrm{O}_{5}-\mathrm{MoO}_{3}-\mathrm{TiO}_{2}-\mathrm{SO}_{4}{ }^{2-}$ & 200 & 3.4 & 100 & 0 & 0 \\
& 250 & 12.9 & 100 & 0 & 0 \\
300 & 51.3 & 100 & 0 & 0 \\
350 & 89.9 & 100 & 0 & 0 \\
400 & 99.2 & 100 & 0 & 0 \\
450 & 100 & 100 & 0 & 0 \\
500 & 100 & 100 & 0 & 0 \\
\hline
\end{tabular}

The turnover frequency (TOF, $\mathrm{h}^{-1}$ ) was calculated for all the samples, at $220^{\circ} \mathrm{C}$, and the results are illustrated in Fig. 12. A visible increase in the TOF values is noted by adding V, Mo or both of them and by sulfating the catalysts, particularly the ternary one (Fig. 12 A). This highlight the crucial role of $\mathrm{V}$ and Mo redox sites and the synergistic effect of the interactions developed between them (V-Mo) and with sulfate groups $\left(\mathrm{V}-\mathrm{SO}_{4}{ }^{2-}-\mathrm{Mo}\right)$ for $\mathrm{DeNO}_{\mathrm{x}}$ ing at low temperature. The inhibiting role of $\mathrm{H}_{2} \mathrm{O}$ and the non-beneficial effect of increasing $\mathrm{NO}$ concentration $([\mathrm{NO}])$ for the low temperature SCR-NO $\left(<220^{\circ} \mathrm{C}\right)$ over $\mathrm{V}_{2} \mathrm{O}_{5}-\mathrm{MoO}_{3}-\mathrm{TiO}_{2}-\mathrm{SO}_{4}{ }^{2-}$ are verified through the decrease of the TOF value after adding water and increasing NO concentration (Fig $12 \mathrm{~B})$. 
(A) Effects of the nature of transition metals (V; Mo) and sulfate addition $\left(\mathrm{SO}_{4}^{2-}\right)$

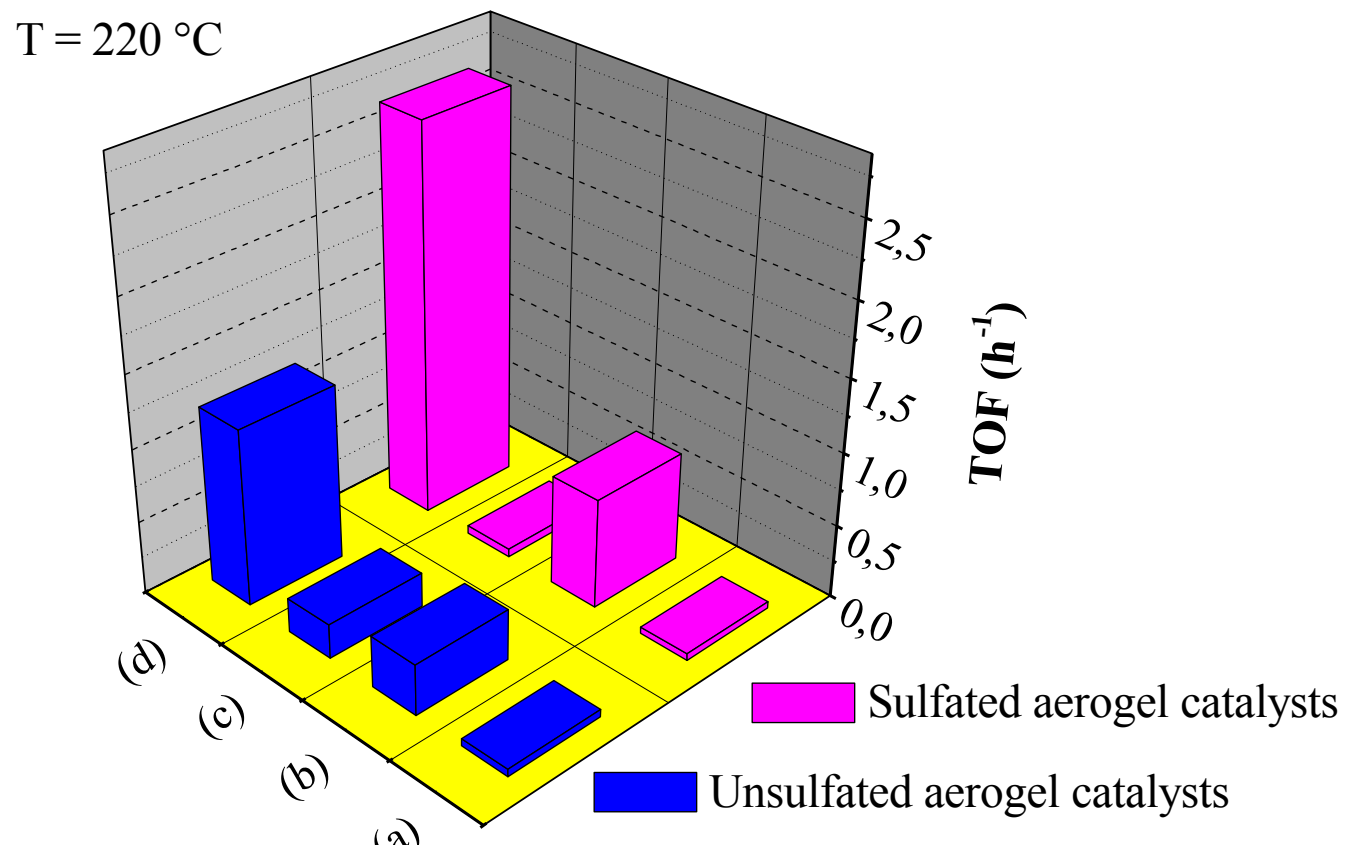

(a)

(a) $\mathrm{TiO}_{2}$; (b) $\mathrm{V}_{2} \mathrm{O}_{5}-\mathrm{TiO}_{2}$; (c) $\mathrm{MoO}_{3}-\mathrm{TiO}_{2}$; (d) $\mathrm{V}_{2} \mathrm{O}_{5}-\mathrm{MoO}_{3}-\mathrm{TiO}_{2}$

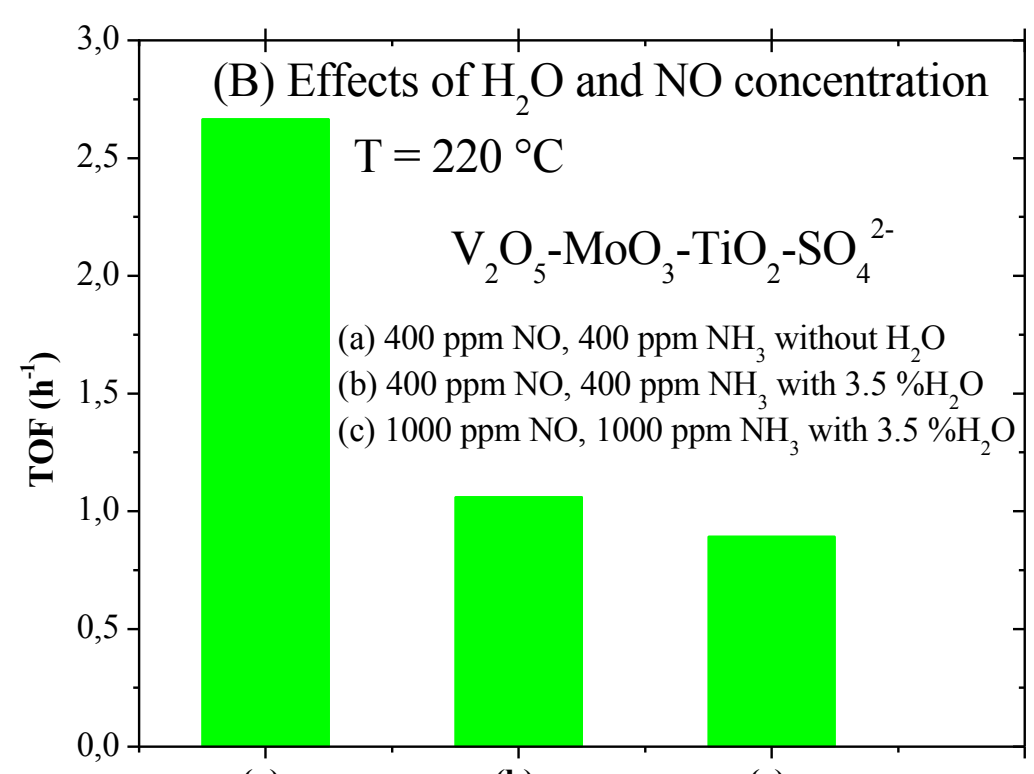

(a)

(b)

(c)

Figure 12. TOF values, defined at $220^{\circ} \mathrm{C}$, over the nanostructured aerogel catalysts: (A)

Effects of the nature of transition metal and sulfate addition: $[\mathrm{NO}]=\left[\mathrm{NH}_{3}\right]=0.04 \%$ without $\mathrm{H}_{2} \mathrm{O}$ and (B) Effect of $\mathrm{NO}$ concentration $\left(0.04\right.$ or $0.1 \%$ ) with $3.5 \% \mathrm{H}_{2} \mathrm{O}$. 


\section{Conclusions and perspectives}

New $\mathrm{V}_{2} \mathrm{O}_{5}-\mathrm{TiO}_{2}, \mathrm{MoO}_{3}-\mathrm{TiO}_{2}, \mathrm{~V}_{2} \mathrm{O}_{5}-\mathrm{MoO}_{3}-\mathrm{TiO}_{2}, \mathrm{TiO}_{2}-\mathrm{SO}_{4}{ }^{2-}, \mathrm{V}_{2} \mathrm{O}_{5}-\mathrm{TiO}_{2}-\mathrm{SO}_{4}{ }^{2-}, \mathrm{MoO}_{3}-$ $\mathrm{TiO}_{2}-\mathrm{SO}_{4}{ }^{2-}$ and $\mathrm{V}_{2} \mathrm{O}_{5}-\mathrm{MoO}_{3}-\mathrm{TiO}_{2}-\mathrm{SO}_{4}{ }^{2-}$ nanostructured and mesoporous aerogel catalysts were developed for the first time in this study for $\mathrm{DeNO}_{\mathrm{x}}$ ing in Diesel Engine. All the obtained aerogels calcined at $500{ }^{\circ} \mathrm{C}$, are characterized by a nanometer size $(\sim 8-13 \mathrm{~nm})$, a good crystallinity of $\mathrm{TiO}_{2}$ anatase phase, high surface area and porosity $\left(\mathrm{S}_{\mathrm{BET}} \geq 73 \mathrm{~m}^{2} / \mathrm{g}\right.$ and $\mathrm{V}_{\mathrm{PT}} \geq$ $0.15 \mathrm{~cm}^{3} / \mathrm{g}$ ) reflecting their developed mesoporous texture and good thermal stability. The nature of supported transition metal ( $\mathrm{V}$ or $\mathrm{Mo}$ ), the addition of sulfate groups $\left(\mathrm{SO}_{4}{ }^{2-}\right)$ and the existence of diverse interactions between $\mathrm{V}, \mathrm{Mo}$ and $\mathrm{SO}_{4}{ }^{2-}$ active species clearly influence the physicochemical properties of aerogel catalysts and strongly affect their SCR activity.

In the SCR-NO by $\mathrm{NH}_{3}$, the synergistic effect between $\mathrm{V}$ and Mo has led to a more reactive $\mathrm{V}_{2} \mathrm{O}_{5}-\mathrm{MoO}_{3}-\mathrm{TiO}_{2}$ ternary catalyst (with maximum of $90 \% \mathrm{NO}$ conversion at $350{ }^{\circ} \mathrm{C}$ ) compared to corresponding binary samples $\left(\mathrm{V}_{2} \mathrm{O}_{5}-\mathrm{TiO}_{2}\right.$ and $\left.\mathrm{MoO}_{3}-\mathrm{TiO}_{2}\right)$. The addition of sulfate enhances the SCR activity of aerogel catalysts, mainly at high temperature, as a consequence of $(i)$ the creation of new strong acid sites by the presence of $\mathrm{SO}_{4}{ }^{2-}$ species and (ii) the modification of the nature and reactivity of actives acid and redox sites by the diverse interactions developed between $\mathrm{V}$, Mo and sulfate.

The simultaneous presence of V, Mo and sulfate allows a good balance between the actives acid and redox sites and leads to a new $\mathrm{V}_{2} \mathrm{O}_{5}-\mathrm{MoO}_{3}-\mathrm{TiO}_{2}-\mathrm{SO}_{4}{ }^{2-}$ catalyst with excellent SCR activity in $150-500{ }^{\circ} \mathrm{C}$ temperature range. This new nanostructured aerogel catalyst demonstrates a similar SCR activity, in the $200-375{ }^{\circ} \mathrm{C}$ temperature range, compared to $\mathrm{V}_{2} \mathrm{O}_{5^{-}}$ $\mathrm{WO}_{3} / \mathrm{TiO}_{2}$ commercial catalyst (EUROCAT), but exhibits a superior catalytic performances at higher temperature $\left(375-500{ }^{\circ} \mathrm{C}\right)$ with respect to the commercial one. It helps to reduce more than $96 \%$ of NO with a high $\mathrm{N}_{2}$ selectivity (75-100\%) using a reaction mixture containing 400 ppm NO and 400 ppm $\mathrm{NH}_{3}$. 
The $\mathrm{V}_{2} \mathrm{O}_{5}-\mathrm{MoO}_{3}-\mathrm{TiO}_{2}-\mathrm{SO}_{4}{ }^{2-}$ aerogel system shows a better resistance to water vapour, at high temperature $\left(>400{ }^{\circ} \mathrm{C}\right)$, than the $\mathrm{V}_{2} \mathrm{O}_{5}-\mathrm{WO}_{3} / \mathrm{TiO}_{2}$ commercial one. Conversely, this later catalyst was found more resistant to $\mathrm{H}_{2} \mathrm{O}$ at lower temperature $\left(<350{ }^{\circ} \mathrm{C}\right)$.

In the presence of water vapour $(3.5 \%)$, the SCR activity of $\mathrm{V}_{2} \mathrm{O}_{5}-\mathrm{MoO}_{3}-\mathrm{TiO}_{2}-\mathrm{SO}_{4}{ }^{2-}$ catalyst is considerably improved, at high temperature, by increasing the NO concentration. Interestingly, $100 \% \mathrm{NO}$ conversion with $100 \% \mathrm{~N}_{2}$ selectivity are achieved, in the $450-500{ }^{\circ} \mathrm{C}$ temperature range, when the NO-SCR reaction was carried out using $[\mathrm{NO}]=\left[\mathrm{NH}_{3}\right]=1000$ ppm.

Further studies are in progress (i) to study the effects of the concentrations of the water vapour and nitrogen oxide on the SCR activity of $\mathrm{V}_{2} \mathrm{O}_{5}-\mathrm{MoO}_{3}-\mathrm{TiO}_{2}-\mathrm{SO}_{4}{ }^{2-}$ and $\mathrm{V}_{2} \mathrm{O}_{5}-\mathrm{WO}_{3} / \mathrm{TiO}_{2}$ catalysts, (ii) to investigate the hydrothermal stability of new $\mathrm{V}_{2} \mathrm{O}_{5}-\mathrm{MoO}_{3}-\mathrm{TiO}_{2}-\mathrm{SO}_{4}{ }^{2-}$ aerogel catalyst in order to improve more its reactivity at low temperatures and (iii) to evaluate the effect of $\mathrm{SO}_{2}$ on its SCR activity.

There are no conflicts of interest to declare

\section{Acknowledgements}

The authors wish to express their sincere thanks to Thomas Cacciaguerra, Valérie Flaud and Prof. Meftah Abdelaziz for XRD, XPS and Raman analysis, respectively. Financial support by Laboratory of Chemistry of Materials and Catalysis (LCMC) of Tunisia and Franco-Tunisian Cooperation (French Institute of Tunisia, SSHN grant) are gratefully acknowledged. 


\section{References}

[1] H. Xu, Z. Fang, Y. Cao, S. Kong, T. Lin, M. Gong, Y. Chen, Influence of Mn/(Mn+Ce) Ratio of $\mathrm{MnO}_{\mathrm{x}}-\mathrm{CeO}_{2} / \mathrm{WO}_{3}-\mathrm{ZrO}_{2}$ Monolith Catalyst on Selective Catalytic Reduction of $\mathrm{NO}_{\mathrm{x}}$ with Ammonia, Chin. J. Catal. 33 (2012) 1927-1937.

[2] F. Gao, X. Tang, H. Yi, S. Zhao, C. Li, J. Li, Y. Shi, X. Meng, A Review on Selective Catalytic Reduction of NOx by $\mathrm{NH}_{3}$ over Mn-Based Catalysts at Low Temperatures: Catalysts, Mechanisms, Kinetics and DFT Calculations, Catalysts 7 (2017) 199-231.

[3] X. Yu, F. Cao, X. Zhu, X, Zhu, X. Gao, Z. Luo, K. Cen, Selective catalytic reduction of NO over Cu-Mn/OMC Catalysts: Effect of preparation method, Aerosol Air Qual. Res. 17 (2017) $302-313$

[4] Z. Ma, X. Wu, Y. Feng, Z. Si, D. Weng, L. Shi, Low-temperature SCR activity and $\mathrm{SO}_{2}$ deactivation mechanism of Ce-modified $\mathrm{V}_{2} \mathrm{O}_{5}-\mathrm{WO}_{3} / \mathrm{TiO}_{2}$ catalyst, Prog. Nat. Sci. Mater. 25 (2015) 342-352.

[5] G. Madia, M. Elsener, M. Koebel, F. Raimondi, A. Wokaun, Thermal stability of vanadiatungsta-titania catalysts in the SCR process, Appl. Catal. B: Environ. 39 (2002) 181-190.

[6] K. Bourikas, Ch. Fountzoula, Ch. Kordulis, Monolayer transition metal supported on titania catalysts for the selective catalytic reduction of $\mathrm{NO}_{\text {b }} \mathrm{NH}_{3}$, Appl. Catal. B : Environ. 52 (2004) $145-153$.

[7] X. Hu, Q. Shi, H. Zhang, P. Wang, S. Zhan, Y. Li, NH${ }_{3}-\mathrm{SCR}$ performance improvement over Mo modified $\mathrm{Mo}(\mathrm{x})-\mathrm{MnO}_{\mathrm{x}}$ nanorods at low temperatures, Catal. Today 297 (2017) 17-26. 
[8] Ch. Fountzoula, N. Spanos, H. K. Matralis, Ch. Kordulis, Molybdenum-titanium oxide catalysts: the influence of the preparation conditions for the selective catalytic reduction of NO by $\mathrm{NH}_{3}$, Appl. Catal . B: Environ. 35 (2002) 295-304.

[9] L. Lietti, I. Nova, P. Forzatti, Selective Catalytic Reduction (SCR) of $\mathrm{NO}$ by $\mathrm{NH}_{3}$ over $\mathrm{TiO}_{2}-$ supported $\mathrm{V}_{2} \mathrm{O}_{5}-\mathrm{WO}_{3}$ and $\mathrm{V}_{2} \mathrm{O}_{5}-\mathrm{MoO}_{3}$ Catalysts. Top. Catal. 11 (2000) 111-122.

[10] O. Kröcher, M. Elsener, Chemical deactivation of $\mathrm{V}_{2} \mathrm{O}_{5} / \mathrm{WO}_{3}-\mathrm{TiO}_{2} \mathrm{SCR}$ catalysts by additives and impurities from fuels, lubrication oils and urea solution I. Catalytic studies, Appl. Catal. B: Environ. 75 (2008) 215-227.

[11] G. Busca, L. Lietti, G. Ramis, F. Berti, Chemical and mechanistic aspects of the selective catalytic reduction of NOx by ammonia over oxide catalysts: A review, Appl. Catal. B: Environ. 18 (1998) 1-36.

[12] S. Brandenberger, O. Kröcher, A. Tissler, R. Althoff, The state of the art in selective catalytic reduction of $\mathrm{NO}_{\mathrm{x}}$ by ammonia using metal-exchanged zeolite catalysts, Catal. Rev. Sci. Eng. 50 (2008) 492-531.

[13] X. Wang, D. Wasterdahl, H. Jingnan, Y. Wu, H. Yin, X. Pan, K. M. Zhang, On-road diesel vehicle emission factors for nitrogen oxides and black carbon in two Chinese cities, Atmos Environ 46 (2012) 45-55.

[14] T. Lee, J. Park, S. Kwon, J. Lee, J. Kim, Variability in operationbased $\mathrm{NO}_{\mathrm{x}}$ emission factors with different test routes, and its effects on the real-driving emissions of light diesel vehicles. Sci. Total Environ. 461-462 (2013) 377-385.

[15] B. Giechaskiel, R. S. Bertoa, T. Lahde, M. Clairotte, M. Carriero, P. Bonnel, M. Maggiore, Evaluation of $\mathrm{NO}_{\mathrm{x}}$ emissions of a retrofitted Euro 5 passenger car for the Horizon prize "Engine retrofit", Environ. Res. 66 (2018) 298-309. 
[16] F. Gholami, M. Thomas, Z. Gholami, M. Vakili, Technologies for the nitrogen oxides reduction from flue gaz: A Review, Sci. Total Environ. 14 (2020) 136712-

[17] H. S. Latha, K.V. Prakash, M. Veerangouda, D. Maski, K.T. Ramappa, A Review on SCR System for $\mathrm{NO}_{x}$ Reduction in Diesel Engine, Int. J. Curr. Microbiol. App. Sci 8 (2019) 15531559.

[18] I. Nova, D. Bounechada, R. Maestri, E. Tronconi, Influence of the Substrate Properties on the Performances of $\mathrm{NH}_{3}$-SCR Monolithic Catalysts for the After treatment of Diesel Exhaust: An Experimental and Modeling Study, Ind. Eng. Chem. Res. 50 (2011) 299-309.

[19] J. Li , R. Z hu, Y. C heng, C. Lambert, R. Yang, Mechanism of Propene Poisoning on FeZSM-5 for Selective Catalytic Reduction of NOx with Ammonia, Environ. Sci. Technol 44 (2010) 1799-1805

[20] P. Granger, V.I. Parvulescu, Catalytic NOx abatement systems for mobile sources: from three-Way to lean burn after-treatment technologies, Chem. Rev. 111 (2011) 3155-3207. [21] D. Worch, W. Suprun, R. Gläser, Supported transition metal-oxide catalysts for HCSCR $\mathrm{DeNO}_{\mathrm{x}}$ with propene, Catal. Today 176 (2011) 309-313.

[22] A.N. Mendes, V.L. Zholobenko, F.T. Starzyk, P.D. Costa, C. Henriques, On the enhancing eff ect of Ce in Pd-MOR catalysts for $\mathrm{NO}_{\mathrm{x}} \mathrm{CH}_{4}$-SCR: A structure-reactivity study, Appl. Catal. B: Environ. 195 (2016) 121-131.

[23] F. Liu, Y. Yu, H. He, Environmentally-benign catalysts for the selective catalytic reduction of NOx from diesel engines: structure-activity relationship and reaction mechanism aspects, Chem. Commun. 50 (2014) 8445-8463.

[24 ] B. Guan, R. Zhan, H. Lin, Z. Huang, Review of state of the art technologies of selective catalytic reduction of NOx from diesel engine exhaust, Appl. Therm. Eng. 66 (2014) 395-414. 
[25] L. Lietti, I. Nova, G. Ramis, L. Dall'Aqua, G. Busca, E. Giamello, P. Forzatti, F. Bregani, Characterization and reactivity of $\mathrm{V}_{2} \mathrm{O}_{5}-\mathrm{MoO}_{3} / \mathrm{TiO}_{2} \mathrm{DeNO}_{\mathrm{x}} \mathrm{SCR}$ catalysts, J. Catal. 187 (1999) 419-435.

[26] L. Casagrande, L. Lietti, I. Nova, P. Forzatti, A. Baiker, SCR of NO by $\mathrm{NH}_{3}$ over $\mathrm{TiO}_{2}$ supported $\mathrm{V}_{2} \mathrm{O}_{5}-\mathrm{MoO}_{3}$ catalysts: reactivity and redox behavior, Appl. Catal. B: Environ. 22 (1999) 63-77.

[27] Y. Qiu, B. Liu, J. Du, Q. Tang, Z. Liu, R. Liu, C. Tao, The monolithic cordierite supported $\mathrm{V}_{2} \mathrm{O}_{5}-\mathrm{MoO}_{3} / \mathrm{TiO}_{2}$ catalyst for $\mathrm{NH}_{3}-\mathrm{SCR}$, Chem. Eng. J. 294 (2016) 264-272.

[28] L. Zhu, Z. Zhong, H.Yang, C. Wang, Effect of $\mathrm{MoO}_{3}$ on vanadium based catalysts for the selective catalytic reduction of $\mathrm{NO}_{x}$ with $\mathrm{NH}_{3}$ at low temperature, J. Environ. Sci. 56 (2016) 169-179.

[29] D. W. Kwon, K. H. Park, S. C. Hong, Enhancement of SCR activity and $\mathrm{SO}_{2}$ resistance on $\mathrm{VO}_{\mathrm{x}} / \mathrm{TiO}_{2}$ catalyst by addition of molybdenum, Chem. Eng. J. 284 (2016) 315-324.

[30] Y. Xu, X. Wu, Q. Lin, J. Hu, R. Ran, D. Weng, $\mathrm{SO}_{2}$ promoted $\mathrm{V}_{2} \mathrm{O}_{5}-\mathrm{MoO}_{3} / \mathrm{TiO}_{2}$ catalyst for $\mathrm{NH}_{3}$-SCR of $\mathrm{NO}_{x}$ at low temperatures, Appl. Catal. A: Gen. 570 (2019) 42-50.

[31] D. Zhang, Z. Ma, B. Wang, T. Zhu, D. Weng, X. Wu, J. Chen, H. Wang, G. Li, J. Zhou, Effect of manganese and/or ceria loading on the $\mathrm{V}_{2} \mathrm{O}_{5}-\mathrm{MoO}_{3} / \mathrm{TiO}_{2} \mathrm{NH}_{3}$ selective catalytic reduction catalyst, J. Rare Earth. 38 (2020) 725-734.

[32] R. Wu, L. Li, N. Zhang, J. He, L. Song, G. Zhang, Z. Zhang, H. He, Enhancement of lowtemperature $\mathrm{NH}_{3}$-SCR catalytic activity and $\mathrm{H}_{2} \mathrm{O} \& \mathrm{SO}_{2}$ resistance over commercial $\mathrm{V}_{2} \mathrm{O}_{5^{-}}$ $\mathrm{MoO}_{3} / \mathrm{TiO}_{2}$ catalyst by high shear-induced doping of expanded graphite, Catal. Today (2020) https://doi.org/10.1016/j.cattod.2020.04.051. 
[33] X. Fan, S. Kang, J. Li, Plasma-enhanced hydrolysis of urea and SCR of $\mathrm{NO}_{\mathrm{x}}$ over $\mathrm{V}_{2} \mathrm{O}_{5^{-}}$ $\mathrm{MoO}_{3} / \mathrm{TiO}_{2}$ : Decrease of reaction temperature and increase of $\mathrm{NO}_{\mathrm{x}}$ conversion, Fuel 277 (2020) 118155.

[34] J. Arfaoui, A. Ghorbel, C. Petitto, G. Delahay, Novel $\mathrm{V}_{2} \mathrm{O}_{5}-\mathrm{CeO}_{2}-\mathrm{TiO}_{2}-\mathrm{SO}_{4}{ }^{2-}$ nanostructured aerogel catalyst for the low temperature selective catalytic reduction of NO by $\mathrm{NH}_{3}$ in excess $\mathrm{O}_{2}$, Appl. Catal. B: Environ. 224 (2018) 264-275.

[35] L. Baraket, A. Ghorbel, P. Grange, Selective catalytic reduction of NO by ammonia on $\mathrm{V}_{2} \mathrm{O}_{5}-\mathrm{SO}_{4}{ }^{2-} / \mathrm{TiO}_{2}$ catalysts prepared by the sol-gel method, Appl. Catal. B: Environ. 72 (2007) $37-43$

[36] L. Zhang, J. Li, H. He, W. Liang, Q. Liang, Effect of $\mathrm{V}_{2} \mathrm{O}_{5}$ on the sulfated $\mathrm{TiO}_{2}$ for low temperature SCR of NO by $\mathrm{NH}_{3}$, Front. Environ. Sci. 3 (2014) 6-12.

[37] Z. Si, D. Weng, X.Wu, Y. Jiang, Roles of Lewis and Brønsted acid sites in NO reduction with ammonia on $\mathrm{CeO}_{2}-\mathrm{ZrO}_{2}-\mathrm{NiO}-\mathrm{SO}_{4}{ }^{2-}$ catalyst, J. Rare Earth. 28 (2010) 727-731.

[38 ] K. Cheng, J. Liu, T. Zhang, J. Li, Z. Zhao, Y. Wei, G. Jiang, A. Duan, Effect of Ce doping of $\mathrm{TiO}_{2}$ support on $\mathrm{NH}_{3}-\mathrm{SCR}$ activity over $\mathrm{V}_{2} \mathrm{O}_{5}-\mathrm{WO}_{3} / \mathrm{CeO}_{2}-\mathrm{TiO}_{2}$ catalyst, J. Environ. Sci. 26 (2014) 2106-2113.

[39] I. Nova, L. Lietti, L. Casagrande, L. Dall'Aqua, E. Giamello, P. Forzatti, Characterization and reactivity of $\mathrm{TiO}_{2}$-supported $\mathrm{MoO}_{3}$ De-NOx SCR catalysts, Appl. Catal. B: Environ. 17 (1998) 245-258.

[40] M. Kang, T. H. Yeon, E. D. Park, J. E. Yie, J. M. Kim , Novel MnO ${ }_{x}$ Catalysts for NO Reduction at Low Temperature with Ammonia, Catal. Lett. 106 (2006) 77-80.

[41] Z. Si, D. Weng, X. Wu, Z. Ma, J. Ma, R. Ran, Lattice oxygen mobility and acidity improvements of $\mathrm{NiO}-\mathrm{CeO}_{2}-\mathrm{ZrO}_{2}$ catalyst by sulfation for $\mathrm{NO}_{\mathrm{x}}$ reduction by ammonia, Catal. Today 201 (2013) 122-130. 
[42] IUPAC, Reporting physisorption data for gas/solid systems with special reference to the determination of surface area and porosity, Pure and Appl. Chem. 57 (1985) 603-619.

[43] M. A. López-Mendoza, R. Nava, C. Peza-Ledesma, B. Millán-Malo, R. Huirache-Acuña, P. Skewes, E. M. Rivera-Muñoz, Characterization and catalytic performance of Co-Mo-W sulfide catalysts supported on SBA-15 and SBA-16 mechanically mixed, Catal. Today 271 (2016) 114-126.

[44] T. Lopez, F. Rojas, R. A. Katz, F. Galindo, A. Balankin, A. Buljanc, Porosity, structural and fractal study of sol-gel $\mathrm{TiO}_{2}-\mathrm{CeO}_{2}$ mixed oxides, J. Solid. State Chem. 177 (2004) 18731885.

[45] G. Imran, R. Maheswari, Mn-incorporated SBA-1 cubic mesoporous silicates: Synthesis and characterization, Mater. Chem. Phys. 161 (2015) 237-242.

[46] P. T. Nguyen, C. Fan, D. Do, D. Nicholson, On the cavitation-like pore blocking in inkbottle pore: evolution of hysteresis loop with neck size. J. Phys. Chem. C 117 (2013) 54755484.

[47] X. Wang, W. Li, X. Wang, J. Zhang, L. Sun, C. Gao, J. Shang, Y. Hu, Q. Zhu, Electrochemical properties of $\mathrm{NiCoO}_{2}$ synthesized by hydrothermal method, RSC Adv. 7 ( 2017) 50753-50759.

[48] H. Chen, Y. Xia, H. Huang, Y. Gan, X. Tao, C. Liang, J. Luo, R. Fang, J. Zhang, W. Zhang, X. Liu, Highly dispersed surface active species of Mn/Ce/TiW catalysts for high performance at low temperature $\mathrm{NH}_{3}$-SCR, Chem. Eng. J. 330 (2017) 1195-1202.

[49] W. Zhao, Q. Zhong, Y. X. Pan, Systematic effects of S-doping on the activity of $\mathrm{V}_{2} \mathrm{O}_{5} / \mathrm{TiO}_{2}$ catalyst for low-temperature $\mathrm{NH}_{3}$-SCR, Chem. Eng. J. 228 (2013) 815-823. 
[50] W. Gao, Z. Zhang, J. Li, Y. Ma, Y. Qu, Surface engineering on $\mathrm{CeO}_{2}$ nanorods by chemical redox etching and their enhanced catalytic activity for $\mathrm{CO}$ oxidation, Nanoscale 7 (2015) 11686-11691.

[51] H. Jensen, A. Soloviev, Z. Li, E. G. Søgaard, XPS and FTIR investigation of the surface properties of different prepared titania nano-powders, Appl. Surf. Sci. 246 (2005) 239-249.

[52] M. J. Muñoz-Batista, A. Kubacka, R. Rachwalik, B. Bachiller-Baeza, M. FernándezGarcía, Green photo-oxidation of styrene over W-Ti composite catalysts, J. Catal. 309 (2014) $428-438$.

[53] J. Zhu, F. Gao, L. Dong, W. Yu, L. Qi, Z. Wang, L. Dong, Y. Chen, Studies on surface structure of $\mathrm{M}_{\mathrm{x}} \mathrm{O}_{\mathrm{y}} / \mathrm{MoO}_{3} / \mathrm{CeO}_{2}$ system $(\mathrm{M}=\mathrm{Ni}, \mathrm{Cu}, \mathrm{Fe})$ and its influence on SCR of $\mathrm{NO}$ by $\mathrm{NH}_{3}$, Appl. Catal. B: Environ. 95 (2010) 144-152.

[54] W. Yu, J. Zhu, L. Qi, C. Sun, F. Gao, L. Dong, Y. Chen, Surface structure and catalytic properties of $\mathrm{MoO}_{3} / \mathrm{CeO}_{2}$ and $\mathrm{CuO} / \mathrm{MoO}_{3} / \mathrm{CeO}_{2}$, J. Colloid Interface Sci. 364 (2011) 435-442. [55] S. T. Choo, Y. G. Lee, I. S. Nam, S.W. Ham, J. B. Lee, Characteristics of $\mathrm{V}_{2} \mathrm{O}_{5}$ supported on sulfated $\mathrm{TiO}_{2}$ for selective catalytic reduction of $\mathrm{NO}$ by $\mathrm{NH}_{3}$, Appl. Catal. A Gen. 200 (2000) $177-188$.

[56] V. I. Pârvulescu, S. Boghosian, V. Pârvulescu, S. M. Jung, P. Grange, Selective catalytic reduction of $\mathrm{NO}$ with $\mathrm{NH}_{3}$ over mesoporous $\mathrm{V}_{2} \mathrm{O}_{5}-\mathrm{TiO}_{2}-\mathrm{SiO}_{2}$ catalysts, J. Catal. 217 (2003) $172-185$

[57] X. Gu, J. Ge, H. Zhang, A. Auroux, J. Shen, Structural, redox and acid-base properties of $\mathrm{V}_{2} \mathrm{O}_{5} / \mathrm{CeO}_{2}$ catalysts, Thermochim. Acta 451 (2006) 84-93.

[58] C. Gannoun, R. Delaigle, P. Eloy, D. P. Debecker, A. Ghorbel, E. M. Gaigneaux, Sol-gel derived $\mathrm{V}_{2} \mathrm{O}_{5}-\mathrm{TiO}_{2}$ mesoporous materials as catalysts for the total oxidation of chlorobenzene, Catal. Comm. 15 (2011) 1-5. 
[59] C. Gannoun, R. Delaigle, P. Eloy, D.P. Debecker, A. Ghorbel, E.M. Gaigneaux, Eff ect of support on $\mathrm{V}_{2} \mathrm{O}_{5}$ catalytic activity in chlorobenzene oxidation, Appl.Catal. A: Gen. 447-448 (2012) 1-6.

[60] S. M. Lee, S. C. Hong, Promotional effect of vanadium on the selective catalytic oxidation of $\mathrm{NH}_{3}$ to $\mathrm{N}_{2}$ over $\mathrm{Ce} / \mathrm{V} / \mathrm{TiO}_{2}$ catalyst, Appl. Catal. B: Environ. 163 (2015) 30-39.

[61] D. Pang, L. Qiu, R. Zhu, F. Ouyang, Silica supported $\mathrm{SO}_{4}{ }^{2-} / \mathrm{TiO}_{2}$ for photocatalytic decomposition of acrylonitrile under simulant solar light irradiation, Chem. Eng. J. 270 (2015) $590-596$.

[62] Z. Li, J. Li , S. Liu, X. Ren, J. Ma, W. Su,Y. Peng, Ultra hydrothermal stability of $\mathrm{CeO}_{2-}$ $\mathrm{WO}_{3} / \mathrm{TiO}_{2}$ for $\mathrm{NH}_{3}-\mathrm{SCR}$ of $\mathrm{NO}$ compared to traditional $\mathrm{V}_{2} \mathrm{O}_{5}-\mathrm{WO}_{3} / \mathrm{TiO}_{2}$ catalyst, Catal. Today $258(2015) 11-16$.

[63] W. Shan, F. Liu, H. He, X. Shi, C. Zhang, A superior Ce-W-Ti mixed oxide catalyst for the selective catalytic reduction of $\mathrm{NO}_{x}$ with $\mathrm{NH}_{3}$, Appl. Catal. B: Environ. 115-116 (2012) 100-106.

[64] W. Shan, F. Liu, H. He, X. Shi, C. Zhang, An environmentally-benign $\mathrm{CeO}_{2}-\mathrm{TiO}_{2}$ catalyst for the selective catalytic reduction of $\mathrm{NOx}$ with $\mathrm{NH}_{3}$ in simulated diesel exhaust, Catal. Today $184(2012)$ 160-165.

[65] H. Al-Kandari, A.M. Mohamed, F. Al-Kharafi, A. Katrib, XPS-UPS,ISS characterization studies and the effect of Pt and $\mathrm{K}$ addition on the catalytic properties of $\mathrm{MoO}_{2-\mathrm{x}}(\mathrm{OH})_{\mathrm{y}}$ deposited on $\mathrm{TiO}_{2}$, J. Electron Spectrosc. Relat. Phenom. 184 (2011) 472- 478.

[66] Z. Liu, S. Zhang, J. Li, J. Zhu, L. Ma, Novel $\mathrm{V}_{2} \mathrm{O}_{5}-\mathrm{CeO}_{2} / \mathrm{TiO}_{2}$ catalyst with low vanadium loading for the selective catalytic reduction of $\mathrm{NOx}_{\text {by }} \mathrm{NH}_{3}$, Appl. Catal. B: Environ. 158-159 (2014) 11-19. 
[67] M. H. Kim, I. S. Nam, Y. G. Kim, Characteristics of Mordenite-Type Zeolite Catalysts Deactivated by $\mathrm{SO}_{2}$ for the Reduction of NO with Hydrocarbons, J. Catal. 179 (1998) 350-360. [68] H. Zhao, S. Bennici, J. Shen, A. Auroux, The influence of the preparation method on the structural, acidic and redox properties of $\mathrm{V}_{2} \mathrm{O}_{5}-\mathrm{TiO}_{2} / \mathrm{SO}_{4}{ }^{2-}$ catalysts, Appl. Catal. A: Gen. 356 (2009) 121-128.

[69] M. A. Larrubia, G. Busca, An ultraviolet-visisble-near infrared study of the electronic structure of oxide supported vanadia tungsta and vanadia molybdena, Mater. Chem. Phys. 72 (2001) 337-436.

[70] Y. Segura, L. Chmielarz, P. Kustrowski, P. Cool, R. Dziembaj, E. F. Vansant, Characterisation and reactivity of vanadia-titania supported SBA-15 in the SCR of NO with ammonia, Appl. Catal. B: Environ. 61 (2005) 69-78.

[71] V. Murgia, E. M. F. Torres, J. C. Gottifredi, E. L. Sham, Sol-gel synthesis of $\mathrm{V}_{2} \mathrm{O}_{5^{-}}$ $\mathrm{SiO}_{2}$ catalyst in the oxidative dehydrogenation of n-butane, Appl. Catal. A: Gen. 312 (2006) 134-143.

[72] M. Høj, T. Kessler, P. Beato, A. D. Jensen, J.-D. Grunwaldt, Structure, activity and kinetics of supported molybdenum oxide and mixed molybdenum-vanadium oxide catalysts prepared by flame spray pyrolysis for propane OHD, Appl Catal. A: Gen. 472 (2014) 29-38.

[73] R. Huirache-Acuña, B. Pawelec, E.M. Rivera-Muñoz, R. Guil-López, J.L.G. Fierro, Characterization and HDS activity of sulfided CoAMoAW/SBA-16 catalysts: Effects of P addition and Mo/(Mo $+\mathrm{W})$ ratio, Fuel 198 (2017) 145-158.

[74] Y. Miao, G. Lu, X. Liu, Y. Guo, Y. Wang, Y. Guo, Effects of preparation procedure in sol-gel method on performance of $\mathrm{MoO}_{3} / \mathrm{SiO}_{2}$ catalyst for liquid phase epoxidation of propylene with cumene hydroperoxide, J. Mol. Catal. A: Chem. 306 (2009) 17-22. 
[75] P. Yuan, C. Cui, W. Han, X. Bao, The preparation of $\mathrm{Mo} / \gamma-\mathrm{Al}_{2} \mathrm{O}_{3}$ catalysts with controllable size and morphology via adjusting the metal-support interaction and their hydrodesulfurization performance, Appl. Catal. A: Gen. 524 (2016) 115-125.

[76] A. Held, P. Florczak, Vanadium, niobium and tantalum modified mesoporous molecular sieves as catalysts for propene epoxidation, Catal. Today 142 (2009) 329-334.

[77] M. Rada, M. Zagrai, S. Rada, A. Bot, E. Culea, Effects on the characteristics of bonding and local structure in molybdenum-lead-lead dioxide glasses and vitroceramics, J. Alloys Compd. 705 (2017) 327-332.

[78] S. El-Korso, S. Bedrane, A. Choukchou-Braham, R. Bachir, The effect of redox properties of ceria-supported vanadium oxides in liquid phase cyclohexene oxidation, RSC Adv. 5 (2015) $63382-63392$.

[79] C. Zhan, F. Chen, H. Dai, J. Yang, M. Zhong, Photocatalytic activity of sulfated Mo-doped $\mathrm{TiO}_{2} @$ fumed $\mathrm{SiO}_{2}$ composite: A mesoporous structure for methyl orange degradation, Chem. Eng. J. 225 (2013) 695-703.

[80] F. Adam, A. Iqbal, Silica supported amorphous molybdenum catalysts prepared via solgel method and its catalytic activity, Micropor. Mesopor Mat. 141 (2011) 119-127.

[81] T. Grzybek, Layered clays as SCR deNO ${ }_{x}$ catalysts, Catal. Today, 119 (2007) 125-132.

[82] L. Lietti, J. L. Alemany, P. Forzatti, G. Busca. G. Ramis, E. Giamello, F. Bregani, Reactivity of $\mathrm{V}_{2} \mathrm{O}_{5}-\mathrm{WO}_{3} / \mathrm{TiO}_{2}$ catalysts in the selective catalytic reduction of nitric oxide by ammonia, Catal. Today 29 (1996) 143-148.

[83] Kapil K. Soni, K. Chandra Mouli, A.K. Dalai, J. Adjaye, Effect of Ti loading on the HDS and HDN activity of KLGO on NiMo/TiSBA-15 catalysts, Micropor. Mesopor. Mater. 152 (2012) 224-234. 
[84] H. Zhao, S. Bennici, J. Cai, J. Shen, A. Auroux, Influence of the metal oxide support on the surface and catalytic properties of sulfated vanadia catalysts for selective oxidation of methanol, J. Catal. 274 (2010) 259-272.

[85] F. Arena, R. Dario, A. Parmaliana, A characterization study of the surface acidity of solid catalysts by temperature programmed methods, Appl. Catal. A: Gen. 170 (1998) 127-137.

[86] P. Forzatti, Present status and perspectives in de-NOx SCR catalysis, Appl. Catal. A 222 (2001) 221-236.

[87] R. Khodayari, C.U. Ingemar Odenbrand, Regeneration of commercial SCR catalysts by washing and sulphation: effect of sulphate groups on the activity, Appl. Catal. B: Environ. 33 (2001) 277-291.

[88] J. P. Chen, R. T. Yang, Selective Catalytic Reduction of $\mathrm{NO}$ with $\mathrm{NH}_{3}$ on $\mathrm{SO}_{4}{ }^{2-}$ $/ \mathrm{TiO}_{2}$ Superacid Catalyst, J. Catal. 139 (1993) 277-288.

[89] S.M. Jung, Investigation of the promotional effect of $\mathrm{V}_{2} \mathrm{O}_{5}$ on the SCR reaction and its mechanism on hybrid catalyst with $\mathrm{V}_{2} \mathrm{O}_{5}$ and $\mathrm{TiO}_{2}-\mathrm{SO}_{4}{ }^{2-}$ catalysts, $\mathrm{P}$. Grange, Appl. Catal. B: Environ. 36 (2002) 207-215.

[90] Q. Zhang, J. Zhang, Z. Song, P. Ning, H. Li, X. Liu, A novel and environmentally friendly $\mathrm{SO}_{4}{ }^{2-} / \mathrm{CeO}_{2}$ catalyst for the selective catalytic reduction of $\mathrm{NO}$ with $\mathrm{NH}_{3}$, J. Ind. Eng. Chem. 34 (2016) 165-171.

[91] Z. Si, D. Weng, X. Wu, J. Yang, B. Wang, Modifications of $\mathrm{CeO}_{2}-\mathrm{ZrO}_{2}$ solid solutions by nickel and sulfate as catalysts for $\mathrm{NO}$ reduction with ammonia in excess $\mathrm{O}_{2}$, Catal. Comm. 11 (2010) 1045-1048.

[92] L. Lietti, P. Forzatti, F. Bregani, Steady-State and Transient Reactivity of $\mathrm{TiO}_{2}$ supported $\mathrm{V}_{2} \mathrm{O}_{5}-\mathrm{WO}_{3}$ DeNOx catalysts: Relevance of vanadium-tungsten interaction on the catalytic activity, Ind. Eng. Chem. Res. 35 (1996) 3884-3892. 
[93] L. Alemany, L. Lietti, N. Ferlazzo, P. Forzatti, G. Busca, E. Giamello, F. Bregani, Reactivity and physicochemical characterization of $\mathrm{V}_{2} \mathrm{O}_{5}-\mathrm{WO}_{3} / \mathrm{TiO}_{2}$ DeNOx catalysts, J. Catal. 155 (1995) 117-130.

[94] J. C. Védrine, Industrial features, Catal. Today 56 (2000) 333-334. 